Discussion Paper No. 10-013

\title{
Bank Owners or Bank Managers: Who is Keen on Risk? Evidence from the Financial Crisis
}

Reint Gropp and Matthias Köhler

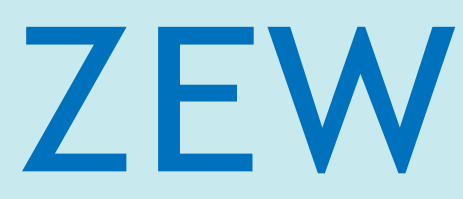

Zentrum für Europäische Wirtschaftsforschung $\mathrm{GmbH}$ Centre for European Economic Research 
Discussion Paper No. 10-013

\title{
Bank Owners or Bank Managers: Who is Keen on Risk? Evidence from the Financial Crisis
}

\author{
Reint Gropp and Matthias Köhler
}

Download this ZEW Discussion Paper from our ftp server:

ftp://ftp.zew.de/pub/zew-docs/dp/dp10013.pdf

Die Discussion Papers dienen einer möglichst schnellen Verbreitung von neueren Forschungsarbeiten des ZEW. Die Beiträge liegen in alleiniger Verantwortung der Autoren und stellen nicht notwendigerweise die Meinung des ZEW dar.

Discussion Papers are intended to make results of ZEW research promptly available to other economists in order to encourage discussion and suggestions for revisions. The authors are solely responsible for the contents which do not necessarily represent the opinion of the ZEW. 


\section{Non-Technical Summary}

We examine in this paper whether owner controlled banks or manager controlled banks suffered larger losses during the financial crisis. We show that banks operating in countries with better shareholder rights and banks with a controlling shareholder recorded larger losses during the crisis than banks operating in countries with poor shareholder rights and banks without a controlling shareholder. In the period before the crisis, however, the owner controlled banks show superior performance.

Both imply that owner controlled banks incurred greater risks compared to manager controlled banks in the pre-crisis period. Economically these effects are large. The profits of banks owned by a majority shareholder operating in a country with strong shareholder rights declined about five times as much during the recent crisis compared to widely held banks operating in countries with weak shareholder rights. These effects are robust to including a wide variety of regulatory, bank specific and country specific variables. We also find that the probability of owner controlled banks to receive government assistance during the crisis is significantly higher than that of manager controlled banks.

We obtain the results using a large dataset of OECD banks, for which we collected information on ownership concentration. In total, the sample consists of more than 1,100 banks for 25 OECD countries. In particular, in addition to most listed banks, the sample also includes many unlisted credit institutions. We think this is important for the broader applicability of the results, since unlisted banks represent the majority of banks in most countries around the world. The greater variability in ownership and corporate governance structures assists us in identifying the effects of governance on bank risk taking.

The results contradict the popular sentiment that managers took advantage of insufficient control by shareholders to obtain compensation packages that disproportionately reward short-term risk taking (e.g. OECD, 2009). They do not support the idea that aligning the interests of management better with shareholders will reduce risk taking of banks. Instead they suggest the opposite. If management is better controlled by shareholders, banks may increase their risk taking. Indeed, one may be able to interpret the observed compensation schemes before the crisis as attempts by shareholders to induce management to increase their risk taking in line with the preferences of shareholders. At the same time, weakening the control of shareholders over management would not only reduce risk, but may entail significant efficiency costs for banks. Privately optimal management compensation schemes may not be socially optimal, as they do not take the externality of a higher probability of bank failure into account. 


\section{Das Wichtigste in Kürze}

Wir untersuchen, ob Banken, die von ihren Eigentümern kontrolliert werden, höhere Verluste infolge der Finanzmarktkrise erlitten haben als Banken, die von ihren Managern kontrolliert werden. Wir zeigen, dass Banken, die in Ländern mit einem höheren Investorenschutz ansässig sind, sowie Banken mit einem Großaktionär höhere Verlusten hinnehmen mussten als Banken, die in Ländern mit einem geringen Investorenschutz beheimatet sind und nicht von einem Großaktionär kontrolliert werden. Im Zeitraum vor der Krise haben die Banken, die von ihren Eigentümern kontrolliert werden, hingegen eine bessere Performance gezeigt.

Das deutet darauf hin, dass Banken, die von ihren Eigentümern kontrolliert werden höhere Risiken vor Ausbruch der Krise eingegangen sind als Banken, die von ihren Managern kontrolliert werden. Ökonomisch betrachtet ist dieser Effekt stark. So sind die Profite der Banken, die von einem Großaktionär kontrolliert werden und in Ländern mit einem hohen Investorenschutz ansässig sind, infolge der Krise fünfmal so stark gesunken wie die Gewinne der Banken, die nicht von einem Großaktionär kontrolliert werden und in Ländern mit geringem Investorenschutz beheimatet sind. Die Ergebnisse ändern sich nicht, wenn wir für eine Vielzahl regulatorischer, bankund länderspezifischer Variablen kontrollieren. Die Resultate deuten ebenfalls darauf hin, dass Banken, die von ihren Eigentümer kontrolliert werden, eher Staatshilfe während der Krise erhalten haben als Banken, die von ihren Eigentümern kontrolliert werden.

Die Ergebnisse widersprechen der öffentlichen Einschätzung, dass die Manager von Banken die unzureichende Kontrolle durch die Eigentümer ausgenutzt haben, um die Vergütungssysteme so zu gestalten, dass das Eingehen kurzfristiger Risiken belohnt wird (z. B. OECD, 2009). Sie unterstützen auch nicht die Hypothese, dass die Risiken einer Bank zurückgehen werden, wenn die Interessen der Manager stärker an die Interessen der Eigentümer gebunden werden. Die Resultate deuten im Gegenteil darauf hin, dass das Risiko zunehmen wird, wenn die Manager besser durch die Eigentümer kontrolliert werden. Vor diesem Hintergrund kann man die Vergütungssysteme, die vor der Krise existierten, als Versuch der Eigentümer ansehen, dass Risiko der Bank zu erhöhen. Wird die Kontrolle durch die Eigentümer gelockert, könnte das nicht nur da Risiko der Banken reduzieren, sondern auch beträchtliche Effizienzkosten nach sich ziehen. Aus diesen Gründen sind privat ausgehandelte Vergütungsverträge für Manager nicht sozial optimal, da sie die Wahrscheinlichkeit, dass eine Bank insolvent wird, nicht berücksichtigen. 


\title{
Bank Owners or Bank Managers: Who is Keen on Risk? Evidence from the Financial Crisis
}

\author{
Reint Gropp ${ }^{1}$ and Matthias Köhler \\ Zentrum für EuropäischeWirtschaftsforschung (ZEW)
}

February, 2010

\begin{abstract}
In this paper, we analyse whether bank owners or bank managers were the driving force behind the risks incurred in the wake of the financial crisis of 2007/2008. We show that owner controlled banks had higher profits in the years before the crisis, and incurred larger losses and were more likely to require government assistance during the crisis compared to manager-controlled banks. The results are robust to controlling for a wide variety of bank specific, country specific, regulatory and legal variables. Regulation does not seem to mitigate risk taking by bank owners. We find no evidence that profit smoothing drives our findings. The results suggest that privately optimal contracts aligning the incentives of management and shareholders may not be socially optimal in banks.
\end{abstract}

Acknowledgement: The authors would like to thank Dominique Demougin, Elu von Thadden, Adalbert Winkler and participants at the Frankfurt School of Management and the EBS Governance Workshop for valuable comments and suggestions.

Keywords: Banks, risk taking, corporate governance, ownership structure, financial crisis

JEL-Classification: G21, G30, G34

L 7, 1

Postfach 103443

D-68034 Mannheim
Tel.: $\quad 0621 / 1235-1481$

Fax: $\quad 0621 / 1235-223$

E-mail: koehler@zew.de

\footnotetext{
${ }^{1}$ Reint Gropp, European Business School, Phone: +49-6723-69-215; email: reint.gropp@ebs.edu
} 
"What I think is a much more fundamental question about the structure and the short-termism [of remuneration schemes] would probably be by looking at the one of the banks that has failed recently. If one of those banks in 2005 decided to be more conservative and hold back in their activity, they more than likely would have had their CEO and board even replaced in 2006 for failing to take advantage of the opportunities, so the structure was one which was one widely supported by players, shareholders and everybody."

Peter Hahn, Former Citigroup Managing Director in a RePort to the Treasury COMMITTEE OF THE BRITISH PARLIAMENT

\section{Introduction}

We examine in this paper whether owner controlled banks or manager controlled banks suffered larger losses during the crisis. We show that it is owner controlled banks that experienced the largest losses. Banks operating in countries with better shareholder rights and banks with a controlling shareholder recorded larger losses during the crisis than banks operating in countries with poor shareholder rights and banks without a controlling shareholder. In the period before the crisis, however, the owner controlled banks show superior performance. This is consistent with fewer private benefits to managers in those banks, but also with higher risk taking before the crisis. ${ }^{2}$ Overall, the results imply that better aligning the incentives of managers with shareholder interests will not result in less risk taking by banks as has been suggested by some in the recent policy debate on management compensation. ${ }^{3}$ Further, privately optimal contracts that align the incentives of management and shareholders may not be socially optimal as these contracts do not take the externality of higher financial fragility into account. When devising management compensation schemes, there appears to be a trade-off between bank efficiency and bank stability. A contract that minimises agency costs may result in socially "excessive" risk taking.

2 The result that owner-controlled banks are riskier highlights the importance of controlling for risk when estimating the importance of private benefits of management in management controlled banks. The results in this paper suggest that risk seems to explain most of the difference in performance between owner-controlled banks and manager-controlled banks. Hence, it may be problematic to attribute differences in performance entirely to private benefits of management in management-controlled banks.

3 In addition to the quote from the New York Times above, see for example "U.S. eyes bank pay overhaul: Administration in early talks on ways to curb compensation across finance," The Wall Street Journal, May 13, 2009 or "U.S. targets excessive pay for top executives," by David Cho, Zachary A. Goldfarb and Tomoeh Murakami Tse, The Washington Post, June 11, 2009; "US SEC proposes say on pay for TARP companies," by James Pehtokoukis, Reuters, July 1, 2009. 
Our results are consistent with long-standing agency theoretic arguments of a negative relationship between risk taking and shareholder control of management. For example Amihud and Lev (1981), Holmstrom and Ricart I Costa (1986) and Hirshleifer and Thakor (1992) argue that managers avoid taking risks due to career concerns and undiversifiable employment risk. According to this view, managers may even spend corporate resources to diversify their companies' operational risk to protect their position in the firm. They also support the recent findings in Fahlenbrach and Stulz (2009) and Beltratti and Stulz (2009), who show that stock price performance during the crisis was worse in those banks, in which the incentives of management were better aligned with the interests of shareholders. The results contradict popular sentiment, also reflected in some policy reports (e.g. OECD, 2009), that in weakly controlled banks, managers were able to obtain compensation packages that rewarded short term risk taking.

We use a large dataset of OECD banks, for which we collected information on ownership concentration. In total, the sample consists of more than 1,100 banks for 25 OECD countries. In particular, in addition to most listed banks, the sample also includes many unlisted credit institutions. We think this is important for the broader applicability of the results, since unlisted banks represent the majority of banks in most countries around the world (see e.g. Gropp and Kashyap, 2009 and Table 1). We also think that the greater variability in ownership and corporate governance structures will help us to identify the effects of governance on risk taking.

We estimate the average performance before the crisis during 2000 to 2006 and the deviation from this average performance during the crisis as a function of shareholder rights and ownership concentration. We find that owner-controlled banks tend to perform better on average before the crisis compared to managercontrolled banks and that owner controlled banks experienced larger losses in the crisis than manager-controlled banks. One innovation of this paper is to use realized losses during the crisis relative to average performance in calm times as a proxy for the risks that were incurred before the crisis. We claim that this approach addresses some of the measurement problems frequently encountered when attempting to measure bank risk. ${ }^{4}$

Relying on the literature (Kose et al., 2008, Laeven and Levine, 2009), we use two proxies for the degree to which management is controlled by shareholders: Ownership concentration (a bank specific variable) and shareholder rights (a country specific variable). Concentrated ownership may help in controlling

4 For example, standard accounting measures, like problem loans or loan loss reserves, tend to be backward looking and limited to on-balance sheet risk; stock price volatilities are limited to listed banks, which constitute only a minority among banks in the OECD (Gropp and Kashyap, 2009 and Table 1). 
management, as large blockholders may posses more ability and greater incentives to monitor management compared to dispersed shareholders (Shleifer and Vishny, 1986). ${ }^{5}$ Better shareholder rights may enable even dispersed shareholders to control management, for instance through calling extraordinary meetings or through the ability to take legal action against management ( $\mathrm{La}$ Porta et al., 1998, 1999).

Theory would tell us that dispersed shareholders have larger incentives to increase risk compared to large blockholders, because they are more diversified (Demsetz and Lehn, 1985 and Esty, 1998). ${ }^{6}$ Large blockholders have greater ability to affect bank performance and bank risk-taking, but it is more difficult for them to diversify their holdings. In addition, large blockholders may try to protect private benefits in the firms that they control (Morck et al., 2005, Stulz, 2005). Hence, the effect of large blockholders on bank risk taking is ambiguous ex ante. On the other hand, the effect of stronger shareholder rights on risk taking is unambiguous. Stronger shareholder rights enable even dispersed small shareholders to exercise better control of management.

We find that shareholders prefer more risk relative to managers irrespective of whether we measure owner control using shareholder rights or ownership concentration. For large blockholders, the ability to control management seems empirically to be more important than the risk reducing effect of lack of diversification. The results are consistent with Saunders et al. (1990) for banks, John et al. (2008) for non-financial firms and Laeven and Levine (2009) for banks. ${ }^{7}$ The evidence shows that bank managers prefer less risk compared to owners, whether dispersed or concentrated. The results are robust to controlling for differences in regulation and supervision across countries as suggested by Laeven and Levine (2009), a host of other legal variables as in Caprio et al. (2007) and differences in profits smoothing (Leuz et al., 2003). We also find that owner controlled banks are significantly more likely to receive government assistance during the crisis, again irrespective of how we measure the ability of owners to control management.

We test and control for the endogeneity of the ownership structure of banks as originally suggested by Demsetz (1983). He argues that the ownership structure of a firm is an endogenous outcome of a competitive selection process in which various advantages and disadvantages of different degrees of ownership

5 They may, however, extract private benefits at the expense of minority shareholders (Shleifer and Vishny, 1997).

6 See also Burkart et al., 2003.

7 To our knowledge only Gorton and Rosen (1995) and Knopf and Teall (1996) find the opposite, namely that manager controlled banks make the riskiest and most unprofitable investment. 
concentration are balanced. The results suggest that different levels of ownership concentration are consistent with value maximisation (Stulz, 1988; Morck et al., 1988 and Demsetz and Villalonga, 2001).

The estimates suggest an economically substantial effect of governance on performance and risk taking: A bank whose largest shareholder owns less than 10 percent and who is headquartered in a country with poor shareholder rights is estimated to have an 2000 to 2006 average ROE of 6.3 percent. In 2008, the ROE was 5 percentage points lower. In contrast, a bank headquartered in a country with strong shareholder rights and where the largest shareholder owns 75 percent of the shares would have an average 2000 to 2006 ROE of 30.1 percent and the 2008 ROE would be 31 percentage points lower, i.e. a ROE of minus one percent.

The literature suggests a number of reasons why agency problems in financial institutions may be particularly important and strong shareholder rights alone may not be sufficient to control managers. For example, Prowse (1997), Macey and O'Hara (2003) and Levine (2004) argue that due to the high level of regulation, principal-agent problems may be more severe in the banking sector than in other sectors. Banking regulations restrict the ability of the market for corporate control to discipline banks (Prowse, 1995), as hostile take-overs in many countries are explicitly discouraged. ${ }^{8}$ Existing management tends to be protected by regulations on entry, mergers, takeovers and administrative rules (Cheng et al., 1989; Prowse, 1997). Further, deposit insurance may aggravate agency problems, since it increases the incentive of shareholders to engage in excessive risk-taking (Prowse, 1997; Macey and O'Hara, 2003). Agency problems may also be exacerbated by the opacity of banks (Morgan, 2002 and Levine, 2004). Opacity creates additional difficulties for shareholders and debt holders to monitor the behaviour of managers and to design contracts that align the objectives of managers and shareholders. Intervention by large shareholders is also less likely if firms are opaque, because the information costs that have to be incurred to understand the institution may be higher (Kahn and Winton, 1998). Seen in this light, the extremely generous performance based compensation packages given to bank managers may be interpreted as an attempt by shareholders to induce management to increase risk taking.

The paper is organized as follows. In the next section, we present the data and some descriptive statistics on ownership structures, performance and the losses

8 For example, the Bundesbank warns against hostile takeovers of large German banks, because "an unfriendly takeover of a big bank could create problems of financial stability", Reuters, April 30, 2007. Furthermore, during the crisis of Société Générale in 2008 the French Prime Minister Francois Filion warned that the government "will not allow Société Générale to be the target of hostile raids by other companies", Bloomberg, January 29, 2008. 
in 2008 among OECD banks. The econometric model and the definitions of the main variables used in the regression are presented in Section 3 and our baseline results in Section 4. In Section 5, we test whether our results hold if we control for bank characteristics. In Section 6 and 7, we check whether they are robust to the inclusion of bank regulatory and other country variables. Section 8 examines whether the results are driven by profit smoothing and shows that owner controlled banks were more likely to require government assistance during the recent crisis. Section 9 concludes.

\section{Data and Econometric Model}

\subsection{Data}

We use a new dataset on the ownership structure of large banks in 25 OECD countries to test our hypotheses. Information on bank shareholders comes from the BankScope (2009) database of Bureau van Dijk. Virtually all of our data on ownership structure are for 2007 and 2008 though we also occasionally use observations from 2005 and 2006. However, since ownership patterns tend to be relatively stable over time, we do not view this as a serious shortcoming ( $\mathrm{La}$ Porta et al., 1998, 1999 and Caprio et al., 2007). BankScope is also the source of balance sheet information. We only include banks that are larger than 1 billion in total assets in 2006. We also require that we have at least three observations over the period between 2000 and 2006 and information on bank performance in 2008. There is some survivorship bias here, as our empirical approach requires that banks survive as an entity until 2008 . We checked whether there were any banks that satisfy the size criterion and the criterion of at least three observations in 2000 to 2006, but are without information for 2008. We were unable to identify a single bank. In our view this is a reflection of the fact that our dataset only contains relatively large banks. In case of serious problems, these banks tend to be either bailed out by the government or merged with another bank. Hence, in order to address this issue head-on, in Section 8 we also estimate the probability that a bank received some form of government assistance as a function of governance variables.

The dataset includes 1,142 banks of which 475 are listed and 667 are unlisted. To our knowledge this is the first paper on bank corporate governance that includes unlisted banks. The regional distribution of banks is reported in Table 1. Most banks are located in the U.S. (317), France (126), Japan (103) and Germany (95). The distribution of banks by specialization is reported in Table 2. Most banks are classified either as commercial bank (526) or as bank holding company (233), but we also have savings banks (95), cooperative banks (92), investment banks (68), mortgage banks (60) and different types of state banks in our sample. The sample, hence, represents a broad snapshot of large banks in OECD countries. 


\subsection{Econometric Model and Main Variables}

We are interested in the relationship between bank performance, bank risk and the strength of shareholder control of management. Ownership and management structures are highly persistent and do not respond to annual changes of performance (Zhou, 2001 and Caprio et al., 2007). Using a panel estimator with fixed effects or first differences may, hence, result in spurious correlation between ownership structure and performance (Zhou, 2001). This eliminates the merits of using a panel (Caprio et al., 2007). Furthermore, with rational managers maximising expected long-term self-interest, it is not clear whether small annual changes in ownership are indicative of notable changes in managerial incentives that are likely to lead to substantive annual changes in performance (Zhou, 2001). As managers are usually with a bank for many years, their incentives depend on the link between their expected long-term selfinterest and the bank's expected long-term performance. Hence, the relationship between ownership structure, risk and performance is likely to be a crosssectional phenomenon (Zhou, 2001). For these reasons, we estimate the following equations for bank performance (1) and bank risk (2):

$\overline{\operatorname{RoE}_{i}}=\alpha_{0}+\alpha_{1} S T A K E_{i}+\alpha_{2}$ RIGHTS $_{c}+\mathrm{AX}+\varepsilon_{i}$,

and

$D R O E_{i}=\beta_{0}+\beta_{1} S_{T A K E}+\beta_{2}$ RIGHTS $_{c}+B X+u_{i}$

$\overline{R o E_{i}}$ is the average performance of bank $i$ during 2000 to 2006 and $D R O E_{i}$ the deviation from average ROE in 2008. DROE is defined as $1-\left[\operatorname{RoE}_{2008}-\overline{R o E}\right]$. It can be interpreted as 1 plus the percentage point drop-off in profits in 2008 relative to the long run average. Hence, a positive coefficient in equation (2) corresponds to larger losses in 2008. A and $B$ are vectors of coefficients. $X$ represents a set of control variables explained below. $\varepsilon_{i}$ and $u_{i}$ are the error terms. The variables of interest are STAKE and RIGHTS.

In line with the literature, STAKE is defined as the size of the largest ownership block and measures the level of ownership concentration in bank $i$ (Glassman and Rhoades, 1980; Cole and Mehran, 1998; Caprio et al., 2007 and Laeven and Levine, 2009). The largest ownership block is defined as the largest direct or indirect stake owned by an individual shareholder or a group of shareholders. A direct stake involves shares registered in the shareholder's name, while indirect ownership involves bank shares that are held by entities that are controlled by the ultimate shareholder. We follow Caprio et al. (2007) and Laeven and Levine (2009) and set every direct and indirect ownership stake below 10 percent to zero. The 10 percent threshold is widely used in the literature (La Porta et al., 1999 and La Porta et al., 2002) and differentiates between widely-held manager- 
controlled banks and banks that have a concentrated ownership structure and may therefore be more likely to be controlled by their shareholders.

The relationship between STAKE and $\overline{R_{0}}$ is not clear a priori. If large shareholders have greater incentives and are better able to control managers than minority shareholders, the relationship between ownership concentration and bank performance should be positive as agency costs and private benefits to management are reduced (Shleifer and Vishny, 1986). However, large shareholders may also have the incentive to extract benefits at the expense of the other (minority) shareholders (Shleifer and Vishny, 1997). This could reduce long term performance of the bank.

Theory tends to suggest a positive relationship between shareholder concentration and risk (DROA). Career concerns (Amihud and Lev, 1981), nondiversifiable human capital risk (Jensen and Meckling, 1976) and private benefits of control (Demsetz and Lehn, 1985 and Kane, 1985) all would result in shareholders preferring more risk compared to managers. However, the ability of shareholders to diversify may matter. If large blockholders are unable to fully diversify, they would not necessarily be interested in more risk than managers. In addition, large shareholders may want to protect private benefits by reducing risk taking (Stultz, 2005) Ultimately, which effect dominates is an empirical matter (John et al., 2008).

Our second proxy for the degree to which managers act in the interest of bank owners is RIGHTS. RIGHTS is an index of anti-director rights taken from La Porta et al. (1999). It is commonly used in the literature to measure the level of investor protection (Caprio et al., 2007 and Laeven and Levine, 2009). It is measured at the country level. If shareholder rights are stronger, even dispersed shareholders are able to exercise better control over management. If this reduces the ability of management to extract private benefits, we would expect a positive relationship between RIGHTS and $\overline{R o E_{i}}$. Similarly, if shareholders push for greater risk-taking to increase their return on investment, we would also expect a positive relationship between RIGHTS and risk (DROE). In particular, minority shareholders may have an incentive to increase risk, given that they are able to fully diversify firm-specific risk (Shleifer and Vishny, 1997). The effect of RIGHTS on risk may, therefore, be larger than the effect of STAKE. ${ }^{9}$

9 Kose et al., 2008 argue that there is an indirect effect of RIGHTS on risk taking that operates through ownership concentration. In countries with strong shareholder protection there are fewer benefits to having dominant shareholders. This may have the consequence that management has more discretionary power and ultimately result in less risk taking. Hence, in all our regressions we control for ownership concentration when examining the effect of shareholder rights on risk and we also control for the endogeneity of ownership concentration using an instrumental variable approach (see Section 4). 
We use different sets of control variables, $X$. Our baseline model includes only bank type dummies. In order to test the robustness of our results, we later also control for state ownership (STATE) and foreign ownership (FOREIGN), as well as whether the bank is listed or not (LIST). Furthermore, we later add several bank-specific variables, such as capital, and country-specific variables, such as regulatory quality, to our baseline model. We also control for profit smoothing. For a complete list and a description of the variables used in the regression analysis see Table 7 . Summary statistics are presented in Table 8.

\section{Descriptive Statistics}

\subsection{Ownership Concentration in the OECD Banking Sector}

Our dataset contains unlisted banks, savings and cooperative banks, as well as a number of specialised credit institutions. As this represents a deviation from the previous literature, we present detailed descriptive statistics for relationships among the main variables of interest. Table 3 presents summary statistics for the largest shareholding according to the type of bank. Table 3 indicates that the degree of ownership concentration varies across bank types. While ownership in bank holding companies and cooperative banks is usually more dispersed, ownership is highly concentrated in state banks and investment banks. There are also significant differences between listed and unlisted banks. As expected, ownership is more dispersed in case of listed credit institutions. However, overall ownership tends to be concentrated with the largest blockholder holding, on average, more than 50 percent of the shares. This is consistent with previous research that finds that banks are generally not widely held (Caprio et al., 2007).

Table 4 indicates that ownership structures also differ across countries. As expected, bank ownership is more dispersed in the Anglo-Saxon countries (U.S., U.K.) compared to most other countries. La Porta et al. (1998) argue that differences in the degree of ownership concentration are caused by different levels of investor protection. If investor rights are better protected, shareholders have less need for a large block of shares to control management. Hence, ownership should be more dispersed in countries where shareholder rights are better protected and more concentrated in countries where investor rights are less protected. This is reflected in Table 4. With a T-test statistic of 6.8, ownership is significantly more concentrated in civil law than in common law countries (La Porta et al., 1998). At the same time, shareholder rights are significantly better protected in common law countries than in civil law countries (with a T-test statistic of 59.6). 


\subsection{Bank Performance and Bank Risk-Taking}

We measure bank performance using return on equity (ROE). Given that we are interested in the effect of governance by shareholders on performance and risk, ROE comes closest to what may enter shareholders' objective functions, given that we are limited to accounting data. Since we are interested in the long-run structural relationship between the performance and the ownership structure of banks, we use the average ROE in the pre-crisis period between 2000 and 2006 to measure long-term performance. Summary statistics for the long-run performance are presented in Table 5. Table 5 indicates that investment banks and bank holding companies had the best and governmental credit institutions the worst average performance in the pre-crisis period. This may be evidence hat the managers of governmental credit institutions had more scope to extract private benefits than the managers of investment banks or bank holding companies, but it may also simply suggest that governmental institutions are poorly managed, as the government may not pursue profit maximizing objectives. Interestingly, savings banks (average ROE of 15 percent) do not necessarily show a lower average ROE compared to commercial banks (14 percent) or bank holding companies (17 percent).

To measure bank risk, we use the 2008 deviation 2008 from the long-term average ROE (DROE). Since risks have materialized during the crisis, we expect that banks that raised their profits between 2000 and 2006 through higher risk-taking should perform worse in 2008. The size of the 2008 deviation from the long-run can, therefore, be used as an indicator for bank risk-taking in the pre-crisis period. Summary statistics for DROE are presented in Table $6 .{ }^{10}$ Table 6 shows that investment banks, bank holding companies and medium and longterm credit banks suffered the largest and cooperative and mortgage banks the smallest losses in 2008 relative to long-run profitability. Investment banks, bank holding companies and medium and long-term credit banks appear to have taken greater risk in the pre-crisis period than cooperative and mortgage banks. To illustrate the relationship between bank performance and bank risk, we plot ROE against DROE. Figure 1 shows a significant (at the 1 percent level) and positive relationship between average performance and risk-taking. This suggests that the superior long-term performance of investment banks and bank holding companies may be attributed to greater risk-taking in the pre-crisis period.

\section{Baseline results}

We start with regressing ROE on STAKE and RIGHTS using OLS without any additional control variables. The results of this simple model are reported in the first column of Table 9. We find that STAKE and RIGHTS are both

${ }^{10}$ Recall that DROE is defined as $1-\left[R o E_{2008}-\overline{R o E}\right]$, and is increasing in the 2008 loss. 
significantly related to average ROE. The positive coefficient for STAKE and RIGHTS indicates that bank performance is higher if ownership is more concentrated and if banks are located in countries with a higher level of investor protection. To check whether the positive relationship is due to higher risk taking, we regress DROE on STAKE and RIGHTS. The results for DROE are reported in the second column of Table 9. Both STAKE and RIGHTS are highly significant. The positive coefficient for RIGHTS indicates that banks in countries with better shareholder protection incurred greater risks. In stark contrast to RIGHTS, we obtain a negative coefficient for STAKE, which is significant at the 1 percent level. Banks with more concentrated owners appear to incur fewer risks.

The results are inconsistent if the ownership structure of a bank is endogenous and the outcome of a competitive selection process in which various advantages and disadvantages of different degrees of ownership concentration are balanced (Demsetz, 1983). For this reason, we instrument STAKE with a dummy variable indicating whether a bank is located in civil law or common law countries (COMMON). Since investor rights are better protected in common law countries, ownership should be more dispersed in common law than in civil law countries. ${ }^{11}$ Table 4 indicates that ownership concentration is indeed significantly higher in civil law than in common law countries. Since COMMON seems to capture differences in the ownership structure reasonably well and since it is largely determined by cultural and historical facts, we regard COMMON as a valid instrument for STAKE. ${ }^{12}$

The results of the instrumental variables regression are reported in columns 3 and 4 of Table 9. While the results for STAKE and RIGHTS remain unchanged in the performance equation (ROE), the sign of STAKE changes from negative to positive in the risk equation (DROE). The reason is simultaneity. If risk increases with ownership concentration because large shareholders are better able to affect risk taking, but ownership concentration decreases as risk increases - which is reasonable since large owners are less diversified than minority shareholders -, the coefficient for STAKE may become negative if we do not control for endogeneity. This is consistent with the literature. Caprio et al. (2007), for example, argue that investor protection alone may not provide a sufficiently powerful corporate governance mechanism to small shareholders. Put differently, even with strong investor protection laws, small shareholders may lack the means to monitor and govern banks. Since tests indicate that

\footnotetext{
11 We obtain very similar results if we use the average ownership concentration of banks in a given country as an instrument as in Laeven and Levine (2009). The results are available from the authors upon request.

12 Test statistics indicate that this is indeed the case.
} 
STAKE is indeed endogenous, we from now on only report results using instrumental variables regressions.

The positive and significant coefficients for STAKE and RIGHTS in the instrumental variable regression indicate that shareholders push for greater risktaking and not managers. This is in line with recent findings by Fahlenbrach and Stulz (2009) and Beltratti and Stulz (2009). They show that stock price performance during the crisis was worse in those banks, in which the incentives of management were better aligned with the interests of shareholders.

In the next step, we add bank type dummy variables. Gropp and Kashyap (2009), for example, show that due to differences in the market for corporate control (cooperative banks cannot be taken over), bank type may be an important determinant of performance (and possibly risk) over the medium term. The results are reported in columns 5 and 6 of Table 9. We refer to this specification as our 'baseline model' below. STAKE and RIGHTS remain highly significant and keep their positive sign indicating that a higher level of ownership concentration and better investor protection increase bank performance and bank risk-taking. In addition, the HOLDING, SAVINGS and COOPERATIVE dummy indicate that the average performance of bank holding companies, savings banks and cooperative banks was significantly better, while the performance of state-banks (STATEBANK) was significantly worse compared to commercial banks (the omitted category). Bank holding companies and savings banks also show, on average, larger downward deviation from long run averages in 2008 as indicated by the significant and positive coefficient for HOLDING and SAVINGS in the risk equation.

Using the baseline coefficients, we find that, evaluated at the sample mean, a one percent increase in ownership concentration, would result in 1.26 percent better average performance during 2000 to 2006 and 0.15 percent worse performance during 2008. A one percent increase in ownership rights, again evaluated at the mean, would result in a 0.74 percent better performance during 2000 to 2006 and 0.12 percent larger loss in 2008 relative to average performance. An illustration may help to better understand the economic magnitudes. The coefficients suggest that a bank whose largest shareholder owns less than 10 percent and who is headquartered in a country with poor shareholder rights (RIGHTS equal to 2, e.g. Switzerland) is estimated to have an 2000 to 2006 average ROE of 6.3 percent. In 2008, the ROE was 5 percentage points lower. In contrast, a bank headquartered in a country with strong shareholder rights (RIGHTS equal to 5, e.g. U.K.) and where the largest shareholder owns 75 percent of the shares would have an average 2000 to 2006 ROE of 30.1 percent and the 2008 ROE would be 31 percentage points lower, i.e. a ROE of minus one percent. 
Overall, therefore, we find that owner controlled banks performed significantly better before the crisis and significantly worse during the crisis compared to manager controlled banks. The effects are economically large. Bank owners seem to have been the driving force behind the risks that banks incurred in the wake of the crisis, not the managers. This is consistent with standard agency theoretic arguments (Amihud and Lev, 1981; Holmstrom and Ricart I Costa, 1986; and Hirshleifer and Thakor, 1992). Risk-averse managers, faced with undiversifiable career and income risk, would like to incur fewer risks than desired by the owners of the bank. If agency conflicts between management and share holders are reduced when shareholder rights are stronger and/or ownership is more concentrated, the outcome is more risk taking. We also find that controlling for shareholder rights, large stakeholders prefer more risk than management. Large stakeholders seem to use their power to control management to increase risk taking. We find no evidence that their lack of diversification or their desire to protect private benefits is empirically important.

In the following sections of the paper we extend and modify our model in order to check the robustness of the results. We add several bank-specific variables to examine whether our results are explained by other bank characteristics that happen to be correlated with the degree of shareholder control of management. Second, as suggested by Laeven and Levine (2009), we check whether the relationship between performance, risk, ownership concentration and shareholder rights depends on the level of banking regulation and supervision. Third, we test whether the results for STAKE and RIGHTS change if we control for other important institutional factors and if the results are robust to controlling for the structure of the banking market in the country where the bank is located. Since our measures for bank risk and performance measure may be influenced by profit smoothing, we additionally check whether our results are robust if we control for profit smoothing. Finally, we test whether the likelihood that a bank received financial support from the government during the crisis is higher if ownership is concentrated and investor rights better protected.

\section{Bank Characteristics}

First, we add a set of dummy variables indicating whether a bank is state-owned (STATE), foreign-owned (FOREIGN) or listed (LIST). The results are reported in the first two columns of Table 10. The dummy variables turn out to be highly significant. The results indicate that listed banks performed better in terms of ROE than banks that are not listed. This is consistent with the idea that better functioning markets for corporate control push managers towards better performance (Gropp and Kashyap, 2009). In contrast, banks owned by the state or by foreign shareholders perform significantly worse, consistent with the literature which usually finds that government (La Porta et al., 2002) and foreign ownership (De Young and Nolle, 1996 and Berger et al., 2000) reduces bank 
performance. Berger et al. (2000) explain the relative inefficiency of foreign banks by organizational diseconomies to operating and monitoring banks from distance. Government ownership reduces bank performance, since politicians acquire control of bank to provide employment, subsidies and other benefits to supporters who return the favor in the form of votes in the next election ( $\mathrm{La}$ Porta et al., 2002). ${ }^{13}$

The results for DROE suggest that listed banks increased their performance in the pre-crisis by greater risk-taking (significant at the 10 percent level). In contrast, controlling for ownership concentration and shareholder rights, banks owned by the government reported, on average, smaller losses in 2008. ${ }^{14}$ The basic result of the paper remains unchanged, however: STAKE and RIGHTS remain significant and retain their positive sign.

Next, we add several bank accounting variables to our model. Consistent with the dependent variable in the performance regressions, they are averaged over the period 2000 to 2006. Since we do not regard them as strictly exogenous to bank performance and bank risk, we do not include them in our baseline model. The results are reported in columns 3 and 4 of Table $10{ }^{15}$ The first variable included is the logarithm of total bank assets to control for bank size (SIZE). SIZE turns out to be significant and positive in the regression with ROE indicating that larger banks performed better between 2000 and 2006 than smaller credit institutions. Larger banks may outperform smaller banks because of economies of scale and scope or greater market power (Berger et al., 2000). However, SIZE is also significant and positive in the risk equation. This suggests that at least part of the superior performance of large banks in the precrisis period can also be attributed to greater risk-taking. Bank risk increases with SIZE, because large banks may be more likely to engage in more risky transactions on the international financial market owing to the large fixed costs necessary to operate globally (Chen and Mazumdar, 1997). They may also have

13 Sapienza (2004), for example, finds that state-owned banks in Italy charge systematically lower interest rates in regions in which the political party affiliated with the bank is stronger.

14 This finding is inconsistent with anecdotal evidence for Germany, where in particular the state-owned Landesbanken were affected by the crisis. Several of these banks had to be bailed out by the Government. We checked whether these banks are in the sample and they are. It turns out that their performance before the crisis was already quite poor, which implies that their losses relative to average performance (DROE) were not as large as for some private sector banks. Furthermore, some Landesbanken recorded their largest losses in 2009. BayernLB, for example, announced additional losses of 3.8 billion euro in December 2009. Since we focus on the losses in 2008, the losses in 2009 are not included. The results for the government ownership dummy should, hence, be interpreted with caution.

15 Note that we lose a few observations due to missing values for the loans and deposits category (see also Table 8). 
incurred greater risks based on the expectation of a government bail-out in case things turn out poorly (Boyd and Runkle, 1993).

The second bank characteristic included is the ratio of total equity to total assets (EQUITY). The effect of EQUITY on performance is not clear a priori. On the one hand, better capitalized banks should have lower refinancing costs owing to lower insolvency risk. This suggests that EQUITY is positively related to longterm performance. However, a higher level of capital may also indicate that banks forego profitable investment opportunities. This should reduce performance. Our results suggest that neither of these effects dominates, since EQUITY is insignificant for ROE. While the effect on long-term performance is not clear a priori, better capitalized banks should have suffered smaller losses during the crisis, based on the idea that banks with larger charter values (more "skin in the game") are hesitant to incur great risks (Keeley, 1990, Cordella and Yeyati, 2003). This implies that EQUITY should be negatively related to DROE in the risk equation. This is what we find. However, the effect of EQUITY is not statistically significant. This contrasts with Beltratti and Stulz (2009), who find a significant and positive link between EQUITY and performance during the crisis. However, when they restrict the sample to large banks they obtain an insignificant coefficient for EQUITY as we do.

To control for the liability side of the bank, we include DEPOSITS defined as the ratio of total deposits to total bank assets. DEPOSITS is significantly (at the 10 percent level) related to long-term performance. The positive coefficient indicates that banks with a larger deposit base have a higher long-term performance than banks that have a smaller deposit base. This is reasonable, since refinancing via deposits is cheaper than other sources of funding, expecially in light of deposit insurance. Some form of explicit deposit insurance existed in all countries of our sample (Barth et al., 2006). Since deposit funding usually also provides a more stable source of funding, in particular when money markets work poorly, we expect that banks with a larger deposit base should have also experienced smaller losses in 2008. The results do not support this hypothesis. DEPOSITS is insignificant for DROE and consistent with evidence in Beltratti and Stulz (2009).

To control for the asset side of the bank, we include LOANS defined as the ratio of total loans to total assets. Banks where LOANS is higher should have a smaller portfolio of securities. We would expect such banks to have performed better during the crisis because their regulatory capital would have been less endangered by the increase in credit spreads that reduces securities values (Beltratti and Stulz, 2009). However, these banks would have also had to increase loan loss reserves on their loans. The results suggest that the second effect dominates, since performance dropped more in 2008 if banks had a larger loan portfolio as indicated by the positive and significant coefficient for LOANS 
in the risk equation. Greater lending activities also seem to have raised average performance in the pre-crisis period. More importantly, however, bank performance and risk are still positively and significantly (at the 1 percent level) related to the degree of ownership concentration and the level of investor protection.

\section{Banking Regulation and Supervision}

Next, we test whether our results are robust to the inclusion of bank regulatory variables. Caprio et al. (2007) and Laeven and Levine (2009) show that bank valuation and risk-taking depend on the level of banking regulation and supervision. Hence, we include RESTRICT, CAPITAL, OFFICIAL and INDEPENDENCE. RESTRICT is an index that measures to which extent the regulator can restrict the activities of banks, while CAPITAL measures regulatory oversight over bank capital. OFFICIAL and INDEPENDENCE control for the power and the independence of the supervisory authority. For a more detailed description of these variables see Table 7 . The results with the banking regulation and supervision variables are reported in Table 11. We follow the literature (e.g. Caprio et al., 2007, Laeven and Levine, 2009) and add each variable separately to our baseline model. A priori, if regulation is effective in reducing risk taking by banks, bank losses in 2008 should be smaller in countries with tighter regulation and a more powerful and independent regulator. However, consistent with less risk taking, we would also expect that banks located in countries with better regulation and supervision performed worse in the pre-crisis period. This suggests that the regulatory variables are negatively related to ROE and DROE.

Our results show the opposite. RESTRICT is positive and significant at the 1 percent level in both regressions, while CAPITAL is positive and marginally significant at the 10 percent level. Limiting banks in their activities (RESTRICT) and the quality of capital requirements (CAPITAL) are positively related to bank performance and bank risk. This corresponds to recent empirical work by Caprio et al. (2007), Beltratti and Stulz (2009) and Laeven and Levine (2009). The latter argue that bank owners may seek to compensate for the utility loss from stricter activity restrictions by increasing risk on remaining activities, while stricter regulations on capital may have motivated banks to engage in offbalance sheet activities to evade capital regulation. OFFICAL and INDEPENDENCE are not significantly related to bank performance and risk, consistent with Caprio et al. (2007).

Finally, we add a variable that captures the level of deposit insurance coverage (COVERAGE). Deposit insurance may aggravate agency problems, since it lowers the incentive of depositors to monitor the bank, because their funds are protected regardless of the outcomes of the investment strategies the bank 
selects (Macey and O'Hara, 2003). This should increase the incentive of shareholders to engage in excessive risk-taking (Prowse, 1997; Macey and O'Hara, 2003). Alternatively, deposit insurance may reduce the incentives for risk taking as it increases the charter value of the bank (Keeley, 1990; Cordella and Yeyati, 2003). Unfairly priced deposit insurance constitutes an implicit government subsidy to the bank, increasing profits and the incentives to remain in business and, therefore, may reduce risk taking. Our results are consistent with the second idea. While COVERAGE is insignificant in the performance equation, it is negative and significantly related to bank risk in the risk equation.

Overall, as in all other regression that include banking regulation and supervision variables STAKE and RIGHTS remain significant and positively related to bank performance and risk-taking consistent with the hypothesis that shareholders and not managers push for greater risk-taking.

\section{Other Country Characteristics}

Finally, to test whether our shareholder rights variables proxies for some other country variables, we follow Beltratti and Stulz (2009) and Caprio et al. (2007) and include variables that control for the overall institutional environment. The first index measures to what extent agents in a country have confidence in contract enforcement and property rights (RULE OF LAW), while the overall quality of the regulatory environment is proxied by REGULATORY QUALITY. Furthermore, we include an index on the level of corruption (CORRUPTION). Since these indices are correlated, we add each index separately to our baseline model. The results are reported in columns 1 to 6 of Table 12. The institutional variables turn out to be mostly insignificant. In contrast, STAKE and RIGHTS remain significant and positively correlated with ROE and DROE.

To control for the structure of the banking system, we use DBAGDP and C3. DBAGDP measures the size of the banking system and is defined as the ratio of total deposit money bank assets to GDP. C3 proxies for the degree of banking market concentration by the sum of the market share of the three largest banks. The results are reported in columns 7 and 8 of Table 12. They suggest that average long-term performance is higher in countries with a smaller banking system and a higher degree of banking market concentration. Bank risk, in contrast, does not seem to be higher in countries with a larger banking sector, but is lower in countries with a higher degree of banking market concentration. The latter may indicate that banks that operate in more concentrated markets may have fewer incentives to engage in more risky activities to increase their profits owing to a lower level of product market competition. This is consistent with the idea that bank charter values reduce risk taking (Keeley, 1990). 
However, even controlling for the banking sector characteristics does not change our results for STAKE and RIGHTS.

Since the financial crisis started in the United States and may have hit U.S. banks hardest, we were concerned that the large number of US banks in our sample - almost one third of all banks in our sample are located in the US could drive our results. For this reason, we check whether our results are robust to the inclusion of a dummy variable for the United States. The results are indeed weaker, but both STAKE and RIGHTS retain their positive relationship with performance before the crisis and losses during the crisis. The effect is significant at the 10 percent level. Furthermore, although we think that ROE comes closest to what may enter shareholders' objective functions, we replace ROE by the return-on-assets (ROA) to see whether our results are robust to the choice of the dependent variable. The results are the same: STAKE and RIGHTS remain positive and significant indicating that shareholders and not managers push for greater risk-taking to increase long-term performance. Both results are not reported for the sake of brevity.

\section{Profit smoothing and bail-outs}

A fundamental concern is that our risk and performance measure may be influenced by profit smoothing incentives of managers. Managers may have the incentive to smooth profits to mask true firm performance and risk-taking and to conceal their private benefits from shareholders (Leuz et al., 2003). They can do so by using their accounting discretion to create reserves for future periods by understating earnings in years of good performance and by reporting higher profits in years with bad performance. Leuz et al. (2003) show that accounting discretion is particularly large in firms with a dispersed ownership structure and weak shareholder rights. This suggests that our results for bank performance may not driven by the incentive of managers to reduce risk, but by greater discretion of managers to smooth profits over time.

To control for profit smoothing, we follow John et al. (2008) and include one minus the ratio of the bank-level standard deviation of operating income divided by the bank-level standard deviation of cash flow operations (SMOOTHING) between 2000 and 2006. The cash flow from operations is measured indirectly by subtracting accruals from operating income. Following Healy (1985), Jones (1991), Leuz et al. (2003) and John et al. (2008), we calculate accruals as follows: ( $\Delta$ total current assets - $\Delta$ cash $)$ - ( $\Delta$ total current liabilities - $\Delta$ short-term debt - $\Delta$ taxes payable) - depreciation and amortization expenses. The latter is assumed to be zero in case of banks, while short-term debt is proxied by deposits and short-term funding. If a bank does not report information on any of these variables, we follow Leuz et al. (2003) and assume that the change in this variable is zero. If managers smooth profits over time the standard deviation 
operating income should be smaller than the standard deviation of cash-flows. Hence, a higher value for SMOOTHING indicates a higher level of earnings smoothing. Summary statistics for SMOOTHING are presented in Table 8.

A priori, we would expect the impact of earnings smoothing on $\overline{R o E_{i}}$ be small, because $\overline{R o E_{i}}$ represents average performance over an extended period. The main focus is therefore on the risk equation with DROE as the dependent variable. Profit smoothing may explain at least part of the smaller drop in earnings in 2008 for banks with weak governance (Leuz et al., 2003). The results for the baseline model including SMOOTHING are reported in columns 1 and 2 of Table 13. Like John et al. (2008), we obtain a negative and significant coefficient for SMOOTHING in the profit equation, even though we use averages over 2000 to 2006. This indicates that even average performance is lower if managers smooth profits over time. Somewhat surprisingly, SMOOTHING is insignificant in the risk equation and the coefficients for STAKE and RIGHTS remain significant and positive. This suggests that our results are not driven by profit smoothing.

Our results indicate that owner-controlled banks incurred greater risks and had to report larger losses in 2008 than banks that are controlled by their managers. As a consequence, owner-controlled banks may be more likely to need financial support from the government during the crisis than manager-controlled banks. To test this hypothesis, we run an instrumental variables probit regression. The dependent variable takes a value of one if a bank has received any kind of financial support from the government during the crisis and zero otherwise (GOVAID). The results for the baseline model are reported in column 3 of Table 13. The results are consistent with our hypothesis. STAKE and RIGHTS are significant and positively related with the probability that a bank has received government aid. This indicates that owner-controlled banks took greater risk in the pre-crisis period and, thus, needed greater financial support from the government than manager-controlled banks once the crisis started to unfold and the incurred risks to materialize. ${ }^{16}$ The probit regression, hence, provides further evidence that banks that are controlled by their owners took greater risk than manager-controlled banks.

${ }^{16}$ We made no attempt to control for the additional equity received in 2008 from the government in the DROE regressions. Most banks reported losses in 2008 and therefore not removing the government equity share understates the effect of STAKE and RIGHTS on DROE. 


\section{Conclusions}

The results in this paper suggest that owner controlled banks experienced higher profits before the crisis and larger losses during the crisis. Both imply that owner controlled banks incurred greater risks compared to manager controlled banks. Economically these effects are large. The profits of banks owned by a majority shareholder operating in a country with strong shareholder rights declined about five times as much during the recent crisis compared to widely held banks operating in countries with weak shareholder rights. These effects are robust to including a wide variety of regulatory, bank specific and country specific variables. We also find that the probability of owner controlled banks to receive government assistance during the crisis is significantly higher than that of manager controlled banks.

We obtain the results using a large dataset of OECD banks, for which we collected information on ownership concentration. In total, the sample consists of more than 1,100 banks for 25 OECD countries. In particular, in addition to most listed banks, the sample also includes many unlisted credit institutions. We think this is important for the broader applicability of the results, since unlisted banks represent the majority of banks in most countries around the world. The greater variability in ownership and corporate governance structures assists us in identifying the effects of governance on bank risk taking.

The results contradict the popular sentiment that managers took advantage of insufficient control by shareholders to obtain compensation packages that disproportionately reward short-term risk taking (e.g. OECD, 2009). They do not support the idea that aligning the interests of management better with shareholders will reduce risk taking of banks. Instead they suggest the opposite. If management is better controlled by shareholders, banks may increase their risk taking. Indeed, one may be able to interpret the observed compensation schemes before the crisis as attempts by shareholders to induce management to increase their risk taking in line with the preferences of shareholders. At the same time, weakening the control of shareholders over management would not only reduce risk, but may entail significant efficiency costs for banks. Privately optimal management compensation schemes may not be socially optimal, as they do not take the externality of a higher probability of bank failure into account. 


\section{Literature}

Amihud, Y. and B. Lev (1981), Risk reduction as managerial motive for conglomerate mergers, Beli Journal of Economics, Vol. 12, 605-617.

Bankscope (2009), Bank-balance sheet and ownership database, provided by Bureau van Dijk.

Barth, J. R., G. Caprio and R. Levine (2006), Rethinking banking regulation Till angels govern, Cambridge University Press.

Beltratti, A. and R. Stulz (2009), Why did some banks perform better during the credit crisis? A cross-country study of the impact of governance and regulation, NBER Working Paper, No. 15180.

Berger A., R. De Young, H. Genay and G. Udell (2000), Globalization of financial institutions: Evidence from cross-border banking performance, Brookings Paper on Economic Activity, Vol. 2, 23-158.

Boyd, J. and D. Runkle (1993): "Size and Performance of Banking Firms: Testing the Predictions of Theory," Journal of Monetary Economics, Vol. 31(1), 47-67.

Burkart, M., F. Panunzi and A. Shleifer (2003), Family firms, Journal of Finance Vol. 58, 2167-2201.

Caprio. G, L. Laeven and R. Levine (2007), Bank valuation and corporate governance, Journal of Financial Intermediation, Vol. 1(4), 584-617.

Chen, A. H. and S. C. Mazumdar (1997), A dynamic model of firewalls and non-traditional banking, Journal of Banking and Finance, Vol. 21, 393416.

Cheng, D. C., W. A. Duncan and L. D. Wall (1989), Financial determinants of takeovers: A note, Journal of Money, Credit and Banking, Vol. 21, 524536.

Cole, R. A. and H. Mehran (1998), The effects of changes in ownership structure on performance: Evidence from the thrift industry, Journal Financial Economics, Vol. 50(3), 291-317.

Cordella, T. and E. L. Yeyati (2003), Bank bailouts: Moral hazard vs. value effect, Journal of Financial Economics, Vol. 12, 300-330.

Demirgüc-Kunt, A. and E. Detragiache (2005), Does deposit insurance increase banking system stability? An empirical investigation, Journal of Monetary Economics, Vol. 49, 1373-1406.

Demsetz, H. (1983), The structure of ownership and the theory of the firm, Journal of Law and Economics, Vol. 26, 375-390.

Demsetz, H. and K. Lehn (1985), The structure corporate ownership: Causes and consequences, Journal of Political Economy, Vol. 93, 1155-1177. 
Demsetz, H. and B. Villalonga (2001), Ownership structure and corporate performance, Journal of Corporate Finance, Vol. 7(3), 209-233.

DeYoung, R. and D. E. Nolle (1996), Foreign-owned banks in the US - Earning market share or buying it?, Journal of Money, Credit and Banking, Vol. 28(4), 622-636.

Esty, B. C. (1998), The impact of contingent liability on commercial bank risk taking, Journal of Financial Economics, Vol. 26, 189-218.

Fahlenbrach, R. and R. Stulz (2009), Bank CEO incentives and the credit crisis, NBER Woking Paper, No. 15212 ,

Glassman C. A. and S. A. Rhoades (1980), Owner vs. manager control effects on bank performance, The Review of Economics and Statistics, Vol. 62(2), 263-270.

Gorton, G. and R. Rosen (1995), Corporate control portfolio choice, and the decline of banking, Journal of Finance, Vol. 50, 1377-1420.

Gropp. R. and A. Kashyap (2009), A new metric for banking integration in Europe, in: Europe and the Euro (A. Alesina and F. Giavazzi, eds.), University of Chicago Press, forthcoming.

Healy, P. M. (1985), The effect of bonus schemes on accounting decisions, Journal of Accounting and Economics, Vol. 7, 85-107.

Hirshleifer, D. and A. V. Thakor (1992), Managerial conservatism, project choice, and debt, Review of Financial Studies, Vol. 5(3), 437-470

Holmstrom, B. and J. Ricart I Costa (1986), Managerial incentives and capital management, Quarterly Journal of Economics, Vol. 101(4), 835-860.

John, K., L. Litov and B. Yeung (2008), Corporate governance and risk-taking, Journal of Finance, Vol. 63(4), 1679-1728.

Jones, J. J. (1991), Earnings management during import relief investigations, Journal of Accounting Research, Vol. 29(2), 193-228.

Kahn, C. and A. Winton (1998), Ownership structure, speculation and shareholder intervention, Journal of Finance, Vol. 53, 99-129.

Kane, E. J. (1985), The gathering crisis in federal deposit insurance, MIT Press, Cambridge, MA.

Kaufman, D., A. Kraay and M. Matruzzi (2008), Governance matters VII: Governance indicators for 1997-2007, World Bank.

Keeley, M. C. (1990), Deposit insurance, risk, and market power in banking, American Economic Review, Vol. 80(5), 1183-1200.

Knopf, J. D. and J. L. Teall (1996), Risk-taking behavior in the US thriftindustry: Ownership structure and regulatory changes, Journal of Banking and Finance, Vol. 20, 1329-1350. 
La Porta, R., F. L. De Silanes, A. Shleifer and R. W. Vishny (1998), Law and finance, Journal of Political Economy, Vol. 106(6), 1113-1155.

La Porta, R., Lopez-de-Silanes, F., Shleifer, A. (1999), Corporate ownership around the world, Journal of Finance, Vol. 54(2), 471-517.

La Porta, R.; F. L. De Silanes and A. Shleifer (2002), Government ownership of banks, Journal of Finance, Vol. 57(2), 265-301.

Laeven, L. and R. Levine (2009), Bank governance, regulation, and risk-taking, Journal of Financial Economics, Vol. 93(2), 259-275.

Leuz, C., D. Nanda and P. D. Wysocki (2003), Earnings management and investor protection: an international comparison, Journal of Financial Economics, Vol. 69, 505-527.

Levine, R. (2004), The corporate governance of banks: A concise discussion of concepts and evidence, World Bank Policy Research Working Paper, No. 3404.

Macey, J. R. and M. O'Hara (2003), The Corporate governance of banks, Federal Reserve Bank of New York Economic Policy Review Vol. 9(1), 91-107.

Morck, R., A. Shleifer and R. W. Vishny (1988), Management ownership and corporate performance-An empirical analysis, Journal of Financial Economics, Vol. 20, 293-315.

Morck, R., D. Wolfenzon and B. Yeung (2005), Corporate Governance, economic Entrenchment, and Growth, Journal of Economic Literature, Vol. 43, 657-722.

Morgan, D. (2002) Rating banks; Risk and uncertainty in an opaque industry, American Economic Review, Vol. 92, 874-888.

Office of Financial Stability (2010), Troubled assets relief program-Transactions report, U.S. Treasury Department.

OECD (2009), Corporate governance and the financial crisis, June.

Petrovic, A. and R. Tusch (2009), National rescue measures in response to the current financial crisis, Legal Working Paper, No. 8, European Central Bank.

Prowse, S. D. (1995), Alternative methods of corporate control in commercial banks, Federal Reserve Bank of Dallas Economic Policy Review Economic Policy Review, Third Quarter, 24-36.

Prowse, S. D. (1997), Corporate control in commercial Banks, Journal of Financial Research, Vol. 20 (4), 509-527.

Sapienza, P. (2007), The effects of government ownership on bank lending, Journal of Financial Economics, Vol. 72, 357-384. 
Saunders, A., E. Strock and N. Travlos (1990), Ownership structure, deregulation and bank risk taking, Journal of Finance, Vol. 45(2), 643654.

Shleifer, A. and R. Vishny (1986), Large shareholders and corporate control, Journal of Political Economy, Vol. 94(3), 461-488.

Shleifer, A. and R. Vishny (1997), A survey on corporate governance, Journal of Finance, Vol. 52(2), 737-781.

Sinn, H.-W. (2009), Kasino Kapitalismus, ECON.

Stulz, R. M. (1988), Managerial control of voting rights: Financing policies and the market for corporate control, Journal of Financial Economics, Vol. $20,25-54$.

Stulz, R. M. (2005), The limits of financial globalization, Journal of Finance Vol. 60, 1595-1638.

White, H. (1980), A heteroskedasticity consistent covariance matrix estimator and a direct test for heteroskedasticity, Econometrica, Vol. 48, 817-838.

World Bank (2009), Financial development and structure database, provided by the World Bank.

Zhou, X. (2001), Understanding the determinants of managerial ownership and the link between ownership and performance: comment, Journal of Financial Economics, Vol. 62, 559-571. 


\section{Table 1: Bank Sample}

The sample includes 1142 banks from 25 OECD countries. Bank data comes from the Bankscope database of Bureau van Dijk. We focus on large banks having at least $\$ 1$ billion in total assets in the last available year. Banks for which we do not have at least three observations for the period between 2000 and 2006 are not included.

\begin{tabular}{lccc}
\hline & Number of Banks & $\begin{array}{c}\text { of which } \\
\text { listed }\end{array}$ & of which unlisted \\
\hline Australia & 13 & 6 & 7 \\
Austria & 50 & 8 & 42 \\
Belgium & 14 & 3 & 11 \\
Canada & 25 & 11 & 14 \\
Denmark & 28 & 19 & 9 \\
Finland & 3 & 1 & 2 \\
France & 126 & 19 & 107 \\
Germany & 95 & 14 & 81 \\
Greece & 10 & 9 & 1 \\
Ireland & 12 & 2 & 10 \\
Italy & 99 & 26 & 73 \\
Japan & 103 & 88 & 15 \\
Korea, Rep. & 14 & 9 & 5 \\
Mexico & 17 & 3 & 14 \\
Netherlands & 21 & 4 & 17 \\
New Zealand & 6 & 0 & 6 \\
Norway & 13 & 10 & 3 \\
Portugal & 10 & 5 & 5 \\
Spain & 25 & 10 & 15 \\
Sweden & 16 & 3 & 13 \\
Switzerland & 59 & 21 & 38 \\
Turkey & 13 & 10 & 3 \\
United Kingdom & 53 & 14 & 39 \\
United States & 317 & 180 & 137 \\
\hline Total & 1,142 & 475 & 667 \\
\hline & & & \\
\hline
\end{tabular}

Table 2: Banks by Specialization

\begin{tabular}{lccc}
\hline & $\begin{array}{c}\text { Number of } \\
\text { Banks }\end{array}$ & $\begin{array}{c}\text { of which } \\
\text { listed }\end{array}$ & of which unlisted \\
\hline Bank Holding \& Holding Company & 233 & 202 & 31 \\
Commercial Bank & 526 & 185 & 341 \\
Cooperative Bank & 92 & 23 & 69 \\
Investment Bank/Securities House & 68 & 20 & 48 \\
Medium \& Long Term Credit Bank & 18 & 6 & 12 \\
Multi-Lateral Governmental Bank & 1 & 0 & 1 \\
Real Estate/Mortgage Bank & 60 & 13 & 47 \\
Savings Bank & 95 & 13 & 82 \\
Specialised Governmental Credit Institution & 49 & 13 & 36 \\
\hline Total & 1,142 & 475 & 667 \\
\hline
\end{tabular}




\section{Table 3: Ownership Concentration by Specialization}

Table 3 presents summary statistics on the degree of ownership concentration for different types of banks. Ownership concentration is measured by the largest direct or indirect ownership stake. Every direct and indirect shareholding below 10 percent is set to zero. Ownership information comes from the Bankscope database of Bureau van Dijk. Means equality tests for listed versus unlisted banks reported at the bottom of the table. $* * * / * * / *$ indicates significance at the $1-/ 5-/ 10-\%$ level.

\begin{tabular}{lcccccc}
\hline & Obs. & Mean & Median & Max. & Min & Std.Dev. \\
\hline Bank Holding \& Holding Company & 233 & 17.94 & 0.00 & 100.00 & 0.00 & 30.54 \\
Commercial Bank & 526 & 57.80 & 50.10 & 100.00 & 0.00 & 38.61 \\
Cooperative Bank & 92 & 32.95 & 25.00 & 100.00 & 0.00 & 33.18 \\
Investment Bank/Securities House & 68 & 67.09 & 100.00 & 100.00 & 0.00 & 40.89 \\
Medium \& Long Term Credit Bank & 18 & 62.99 & 65.00 & 100.00 & 0.00 & 36.50 \\
Multi-Lateral Governmental Bank & 1 & 60.11 & 60.11 & 60.11 & 60.11 & 0.00 \\
Real Estate/Mortgage Bank & 60 & 58.99 & 61.65 & 100.00 & 0.00 & 37.64 \\
Savings Bank & 95 & 53.99 & 50.10 & 100.00 & 0.00 & 32.96 \\
Specialised Governmental Credit & & & & & & \\
Institution & 49 & 76.87 & 85.00 & 100.00 & 22.50 & 24.60 \\
\hline Total & 1,142 & 48.87 & 50.10 & 100.00 & 0.00 & 39.83 \\
\hline - Listed Banks & 475 & 18.19 & 0.00 & 100.00 & 0.00 & 26.86 \\
- Unlisted Banks & 667 & 70.17 & 85.00 & 100.00 & 0.00 & 32.49 \\
\hline
\end{tabular}

T-test statistic on the sample mean: Listed Banks vs. Unlisted Banks: 29.8151***. 


\section{Table 4: Ownership Concentration and Shareholder Rights by Country}

Table 4 presents summary statistics on the degree of ownership concentration and investor protection for different countries. Ownership concentration is measured by the largest direct or indirect ownership stake. Every direct and indirect shareholding below 10 percent is set to zero. Ownership information comes from Bankscope. Investor protection is measured by the anti-director rights index (La Porta et al., 1998). Means equality tests for common law and civil law countries are reported at the bottom of the table. $* * * / * * / *$ indicates significance at the 1-/5-/10-\% level. Common law countries are Australia, Canada, Ireland, New Zealand, the United Kingdom and the United States. All other countries are civil law countries.

\begin{tabular}{lccccccc}
\hline & Obs. & Mean & Median & Max. & Min. & Std.Dev. & RIGHTS \\
\hline Australia & 13 & 42.76 & 99.77 & 100.00 & 11.44 & 35.58 & 4 \\
Austria & 50 & 68.96 & 73.94 & 100.00 & 0.00 & 27.40 & 2 \\
Belgium & 14 & 73.38 & 99.77 & 100.00 & 11.44 & 35.58 & 0 \\
Canada & 25 & 43.73 & 50.10 & 100.00 & 0.00 & 41.38 & 5 \\
Denmark & 28 & 26.59 & 0.00 & 100.00 & 0.00 & 36.44 & 2 \\
Finland & 3 & 59.12 & 56.90 & 100.00 & 20.48 & 39.80 & 3 \\
France & 126 & 61.17 & 56.46 & 100.00 & 0.00 & 34.51 & 3 \\
Germany & 95 & 78.44 & 92.50 & 100.00 & 0.00 & 27.89 & 1 \\
Greece & 10 & 54.49 & 47.17 & 100.00 & 0.00 & 31.34 & 2 \\
Ireland & 12 & 83.33 & 100.00 & 100.00 & 0.00 & 38.92 & 4 \\
Italy & 99 & 49.90 & 51.03 & 100.00 & 0.00 & 36.77 & 1 \\
Japan & 103 & 15.76 & 0.00 & 100.00 & 0.00 & 31.03 & 4 \\
Korea, Rep. & 14 & 54.30 & 61.25 & 100.00 & 0.00 & 38.13 & 2 \\
Mexico & 17 & 75.43 & 99.97 & 100.00 & 0.00 & 35.28 & 1 \\
Netherlands & 21 & 77.43 & 100.00 & 100.00 & 0.00 & 32.04 & 2 \\
New Zealand & 6 & 100.00 & 100.00 & 100.00 & 100.00 & 0.00 & 4 \\
Norway & 13 & 2.61 & 0.00 & 34.00 & 0.00 & 9.42 & 4 \\
Portugal & 10 & 64.72 & 86.20 & 100.00 & 0.00 & 42.76 & 3 \\
Spain & 25 & 35.02 & 14.98 & 100.00 & 0.00 & 37.19 & 4 \\
Sweden & 16 & 70.60 & 100.00 & 100.00 & 0.00 & 40.30 & 3 \\
Switzerland & 59 & 73.77 & 88.10 & 100.00 & 0.00 & 32.77 & 2 \\
Turkey & 13 & 72.38 & 76.99 & 100.00 & 30.15 & 22.49 & 2 \\
United Kingdom & 53 & 72.29 & 100.00 & 100.00 & 0.00 & 41.68 & 5 \\
United States & 317 & 29.00 & 13.65 & 100.00 & 0.00 & 32.20 & 5 \\
\hline Total & 1,142 & 48.87 & 50.10 & 100.00 & 0.00 & 39.83 & 3.26 \\
\hline - of which common & & & & & & & \\
law countries & 426 & 38.72 & 49.00 & 100.00 & 0.00 & 38.67 & 4.92 \\
- of which civil law & & & & & & & \\
countries & 716 & 54.91 & 53.65 & 100.00 & 0.00 & 39.31 & 2.27 \\
\hline$\quad$ T-tst ststc & & 5 & & & \\
\end{tabular}

T-test statistic on the sample mean: Common law countries vs. civil law countries: $6.7981 * * *$

We additionally test whether anti-director rights (RIGHTS) significantly differ for common law and civil law countries.

\begin{tabular}{ccccccc}
\hline & Obs. & Mean & Median & Max. & Min & Std.Dev. \\
\hline $\begin{array}{c}\text { - of which common } \\
\text { law countries }\end{array}$ & 426 & 4.92 & 5 & 5 & 4 & 0.26 \\
$\begin{array}{c}\text { - of which civil law } \\
\text { countries }\end{array}$ & 716 & 2.27 & 2 & 4 & 0 & 1.14 \\
\hline
\end{tabular}

T-test statistic on the sample mean: Common law countries vs. civil law countries: $-59.60 * * *$ 


\section{Table 5: Summary Statistics for Bank Performance ( $\overline{R o E_{i}}$ )}

Table 5 presents summary statistics for bank performance. Data on bank perforrmance comes from the Bankscope database of Bureau van Dijk. Bank performance is measured by the average return-onequity (ROE) in period between 2000 and 2006. Banks for which we do not have at least three observations are not included. ROE is winsorized at the 1-and 99-\% level.

\begin{tabular}{lcccccc}
\hline & Obs. & Mean & Median & Max. & Min. & Std.Dev. \\
\hline Bank Holding \& Holding Company & 233 & 0.17 & 0.17 & 0.46 & -0.16 & 0.08 \\
Commercial Bank & 526 & 0.14 & 0.14 & 0.46 & -0.16 & 0.11 \\
Cooperative Bank & 92 & 0.12 & 0.11 & 0.46 & 0.02 & 0.05 \\
Investment Bank/Securities House & 68 & 0.20 & 0.19 & 0.46 & -0.02 & 0.14 \\
Medium \& Long Term Credit Bank & 18 & 0.11 & 0.10 & 0.27 & 0.04 & 0.06 \\
Multi-lateral Governmental Bank & 1 & 0.03 & 0.03 & 0.03 & 0.03 & 0.00 \\
Real Estate/Mortgage Bank & 60 & 0.12 & 0.11 & 0.34 & -0.16 & 0.08 \\
Savings Bank & 95 & 0.15 & 0.14 & 0.46 & 0.03 & 0.07 \\
Specialised Governmental Credit & & & & & & \\
Institution & 49 & 0.10 & 0.10 & 0.46 & -0.13 & 0.10 \\
\hline Total & 1,142 & 0.14 & 0.14 & 0.46 & -0.16 & 0.10 \\
\hline
\end{tabular}

\section{Table 6: Summary Statistics for Bank Risk (DROE)}

Table 6 presents summary statistics for bank risk. Data on bank risk comes from the Bankscope database of Bureau van Dijk. Bank risk is measured by is measured by the deviation in ROE in 2008 from its average performance in the period between 2000 and 2006. Banks for which we do not have at least three observations are not included. DROE is defined as $1-\left[\operatorname{RoE}_{2008}-\overline{R o E}\right]$. A larger value for DROE, hence, indicates greater losses in 2008. To eliminate outliers, DROE is winsorized at the 1-and 99-\% level.

\begin{tabular}{lcccccc}
\hline & Obs. & Mean & Median & Max. & Min. & Std.Dev. \\
\hline Bank Holding \& Holding Company & 233 & 1.19 & 1.11 & 2.50 & 0.41 & 0.28 \\
Commercial Bank & 526 & 1.11 & 1.05 & 2.50 & 0.41 & 0.28 \\
Cooperative Bank & 92 & 1.06 & 1.04 & 1.37 & 0.96 & 0.08 \\
Investment Bank/Securities House & 68 & 1.17 & 1.06 & 2.50 & 0.41 & 0.37 \\
Medium \& Long Term Credit Bank & 18 & 1.19 & 1.13 & 1.19 & 0.41 & 0.37 \\
Multi-lateral Governmental Bank & 1 & 0.99 & 0.99 & 0.99 & 0.99 & 0.00 \\
Real Estate/Mortgage Bank & 60 & 1.05 & 1.04 & 2.31 & 0.41 & 0.26 \\
Savings Bank & 95 & 1.16 & 1.08 & 2.50 & 0.70 & 0.27 \\
Specialised Governmental Credit & & & & & & \\
Institution & 49 & 1.09 & 1.03 & 2.42 & 0.41 & 0.27 \\
\hline Total & 1,142 & 1.13 & 1.06 & 2.50 & 0.41 & 0.28 \\
\hline
\end{tabular}


Table 7: Description of Variables

\begin{tabular}{|c|c|}
\hline Variable & Description \\
\hline$\overline{\overline{R o E_{i}}}$ & $\begin{array}{l}\text { Average return-on-equity over the period between } 2000 \text { and } 2006 \text { for bank } i \text {. To eliminate outliers, ROE is winsorized at the } 1-\text { and } 99 \text {-percent level. } \\
\text { Source: Bankscope (2008) }\end{array}$ \\
\hline DROE & $\begin{array}{l}\text { DROE is defined as } 1-\left[\operatorname{RoE}_{2008}-\overline{R o E}\right] \text {. A larger value for DROE, hence, indicates greater losses in } 2008 \text { and thus greater risk-taking in the period } \\
\text { between } 2000 \text { and } 2006 \text {. To eliminate outliers, DROE is winsorized at the } 1 \text { - and 99-percent level. Source: Bankscope (2009) }\end{array}$ \\
\hline STAKE & $\begin{array}{l}\text { The largest direct or indirect stake that an individual shareholder or an affiliated group of shareholders has. A direct stake involves shares registered in } \\
\text { the shareholder's name, while indirect ownership involves bank shares that are held by entities that are controlled by the ultimate shareholder. Every } \\
\text { direct and indirect ownership stake below } 10 \text { percent is set to } 0 \text { Source: Bankscope (2008) }\end{array}$ \\
\hline RIGHTS & $\begin{array}{l}\text { Index of anti-director rights for the country. Formed by adding one when: (1) the country allows shareholders to mail their proxy vote, ( } 2 \text { ) shareholders } \\
\text { are not required to deposit their shares prior to the General Shareholders' Meeting, (3) cumulative voting or proportional representation of minorities on } \\
\text { the board of directors is allowed, (4) an oppressed minorities mechanism is in place, (5) the minimum percentage of share capital that entitles a } \\
\text { shareholder to call for an Extraordinary Shareholders' Meeting is less than or equal to } 10 \text { percent (the sample median), or (6) when shareholders have } \\
\text { preemptive rights that can only be waived by a shareholders meeting. The range for the index is from zero to six. Source: La Porta et al. (1998). }\end{array}$ \\
\hline SAVINGS & Dummy variable indicating whether a bank is classified as savings bank. Source: Bankscope (2008) \\
\hline COOPERATIVE & Dummy variable indicating whether a bank is classified as cooperative bank. Source: Bankscope (2008) \\
\hline HOLDING & Dummy variable indicating whether a bank is classified as bank holding company bank. Source: Bankscope (2008) \\
\hline INVESTMENT & Dummy variable indicating whether a bank is classified as investment bank or a securities house. Source: Bankscope (2008) \\
\hline MORTGAGE & Dummy variable indicating whether a bank is classified as real-estate or mortgage bank. Source: Bankscope (2009) \\
\hline STATEBANK & $\begin{array}{l}\text { Dummy variable indicating whether a bank is classified as a multi-lateral governmental bank, specialized governmental credit institution or medium- } \\
\text { and long-term credit bank. Source: Bankscope (2008) }\end{array}$ \\
\hline FOREIGN & Dummy variable indicating whether the largest shareholder is a foreign entity or individual. Source: Bankscope (2008) \\
\hline STATE & Dummy variable indicating whether the state or any other governmental institution is the largest shareholder. Source: Bankscope (2008) \\
\hline LIST & Dummy variable indicating whether a bank is listed on a stock exchange. Source: Bankscope (2008) \\
\hline SMOOTHING & $\begin{array}{l}\text { SMOOTHING measures whether bank managers have smoothed profits over time. It is defined as one minus the ratio of the bank-level standard } \\
\text { deviation of operating income divided by the bank-level standard deviation of cash flow operations between } 2000 \text { and } 2006 \text {. A larger value for } \\
\text { SMOOTHING indicates greater profit smoothing. The cash flow from operations is measured indirectly by subtracting accruals from operating income. } \\
\text { Following Healy (1985), Jones (1991), Leuz et al. (2003) and John et al. (2008), we calculate accruals as follows: ( } \Delta \text { total current assets - } \Delta \text { cash) - } \\
\text { ( } \Delta \text { total current liabilities - } \Delta \text { short-term debt - } \Delta \text { taxes payable) - depreciation and amortization expenses. Depreciation and amortization expenses is } \\
\text { assumed to be zero in case of banks. Short-term debt is proxied by deposits and short-term funding. To eliminate outliers, SMOOTHING is winsorized } \\
\text { at the 1- and 99-percent level. Bank data is from Bankscope (2008). }\end{array}$ \\
\hline GOVAID & $\begin{array}{l}\text { Dummy variable indicating whether a bank received any kind of financial support from the government during the crisis. Source: Petrovic and Tusch } \\
\text { (2009), Sinn (2009) and Office of Financial Stability (2010). For countries where we did not find any information on government rescue programs for } \\
\text { the financial sector, we randomly checked on the internet whether banks received any kind of financial support form the government during the crisis. }\end{array}$ \\
\hline SIZE & $\begin{array}{l}\text { Average of the logarithm of total bank assets (\$ Million) in the period between } 2000 \text { and } 2006 \text {. To eliminate outliers, SIZE is winsorized at the } 1 \text { - and } \\
\text { 99-percent level. Source: Bankscope (2008) }\end{array}$ \\
\hline
\end{tabular}



percent level. Source: Bankscope (2008)

DEPOSITS Average ratio of total deposits to total bank assets in the period between 2000 and 2006. To eliminate outliers, DEPOSITS is winsorized at the 1- and 99-percent level. Source: Bankscope (2008)

SDPROFIT Standard deviation of net operating profits in the period between 2000 and 2006. To eliminate outliers, SDPROFIT is winsorized at the 1- and 99percent level. Source: Bankscope (2008)

LOANS

RESTRICT Average ratio of total loans to total bank assets in the period between 2000 and 2006. To eliminate outliers, LOANS is winsorized at the 1- and 99percent level. Source: Bankscope (2008)

CAPITAL

Index of regulatory restrictions on banks ability to engage in securities market activities, the insurance business and conduct real estate activities. The index ranges from 4 to 12 with higher values indicating more restrictions. Data are for 2003. Source: Barth, Caprio, and Levine (2006).

Capital regulatory index. The index that includes information on the following questions. 1. Is the minimum capital-asset ratio requirement risk weighted in line with the Basel guidelines? 2. Does the minimum ratio vary as a function of market risk? 3. Are market value of loan losses not realized in accounting books deducted from capital? 4. Are unrealized losses in securities portfolios deducted? 5. Are unrealized foreign exchange losses deducted? 6. What fraction of revaluation gains is allowed as part of capital? 7. Are the sources of funds to be used as capital verified by the regulatory/supervisory authorities? 8. Can the initial disbursement or subsequent injections of capital be done with assets other than cash or governmen securities? 9. Can initial disbursement of capital be done with borrowed funds? The index ranges from 0 to 10 with higher values indicating greater stringency. Data are for 2003. Source: Barth, Caprio, and Levine (2006).

OFFICIAL Index of official supervisory power. Adds one for an affirmative response to each for the following 14 questions: 1. Does the supervisory agency have the right to meet with external auditors to discuss their report without the approval of the bank? 2.Are auditors required by law to communicate directly to the supervisory agency any presumed involvement of bank directors or senior managers in elicit activities, fraud, or insider abuse? 3.Can supervisors take legal action against external auditors for negligence? 4.Can the supervisory authority force a bank to change its internal organizational structure? 5.Are off-balance sheet items disclosed to supervisors? 6. Can the supervisory agency order the bank's directors or management to constitute provisions to cover actual or potential losses? 7. Can the supervisory agency suspend the directors' decision to distribute: a) Dividends? b) Bonuses? c) Management fees? 8.Can the supervisory agency legally declare-such that this declaration supersedes the rights of bank shareholders-that a bank is insolvent? 9.Does the Banking Law give authority to the supervisory agency to intervene that is, suspend some or all ownership rights-a problem bank? 10.Regarding bank restructuring and reorganization, can the supervisory agency or any other government agency do the following: a) Supersede shareholder rights? b) Remove and replace management? c) Remove and replace directors? shareholder rights? b) Remove and replace management? c) Remove and replace directors? The index ranges from 0 to 14 with higher values indicating greater power of the supervisory authority. Data are for 2003. Source: Barth, Caprio, and Levine (2006).

INDEPENDENCE The degree to which the supervisory authority is independent from the government and legally protected from the banking system. The index ranges from 0 to 2 with higher values indicating greater independence of the supervisory authority. Data are for 2003. Source: Barth, Caprio, and Levine (2006).

COVERAGE Ratio of deposit insurance coverage to per capita Gross Domestic Product (GDP) in 2003. Source: Demirgüc-Kunt et al. (2005)

RULE OF LAW The average value the Rule of Law Index in the period between 2000 and 2006. Source: Kaufman et al. (2008)

REGULATORY The average value the Regulatory Quality in the period between 2000 and 2006. Source: Kaufman et al. (2008)

QUALITY

CORRUPTION

DBAGDP

The average value the Freedom of Corruption Index in the period between 2000 and 2006. Source: Kaufman et al. (2008)

C3

Ratio of deposit-money bank assets to GDP. Source: World Bank (2009)

Market share of the three largest credit institutions. Source: World Bank (2009) 
Table 8: Summary Statistics

Table 8 presents summary statistics for the variables used in the regression analysis. For a complete list and a description of the variables see Table 7.

\begin{tabular}{lcccccc}
\hline Variable & Obs. & Mean & Median & Max. & Min. & Std.Dev. \\
\hline ROE & 1142 & 0.14 & 0.14 & 0.46 & -0.16 & 0.10 \\
DROE & 1142 & 1.13 & 1.06 & 2.50 & 0.41 & 0.28 \\
STAKE & 1142 & 48.87 & 50.10 & 100.00 & 0.00 & 39.84 \\
RIGHTS & 1142 & 3.27 & 3.00 & 5.00 & 0.00 & 1.58 \\
HOLDING & 1142 & 0.20 & 0.00 & 1.00 & 0.00 & 0.40 \\
SAVINGS & 1142 & 0.08 & 0.00 & 1.00 & 0.00 & 0.28 \\
COOPERATIVE & 1142 & 0.08 & 0.00 & 1.00 & 0.00 & 0.27 \\
INVESTMENT & 1142 & 0.06 & 0.00 & 1.00 & 0.00 & 0.24 \\
MORTGAGE & 1142 & 0.05 & 0.00 & 1.00 & 0.00 & 0.22 \\
STATEBANK & 1142 & 0.06 & 0.00 & 1.00 & 0.00 & 0.24 \\
LIST & 1142 & 0.42 & 0.00 & 1.00 & 0.00 & 0.49 \\
FOREIGN & 1142 & 0.20 & 0.00 & 1.00 & 0.00 & 0.40 \\
STATE & 1142 & 0.05 & 0.00 & 1.00 & 0.00 & 0.21 \\
SMOOTHING & 1100 & 0.89 & 0.94 & 0.99 & -0.31 & 0.16 \\
SIZE & 1142 & 8.79 & 8.62 & 13.57 & 5.92 & 1.71 \\
CAPITAL & 1142 & 8.79 & 7.48 & 52.18 & 1.02 & 7.23 \\
DEPOSITS & 1079 & 0.55 & 0.61 & 0.93 & 0.00 & 0.26 \\
LOANS & 1123 & 0.60 & 0.66 & 0.98 & 0.01 & 0.23 \\
SDPROFIT & 1101 & 120.31 & 17.36 & 2244.96 & 0.49 & 332.42 \\
RESTRICT & 1142 & 8.80 & 10.00 & 12.00 & 4.00 & 2.21 \\
CAPITAL & 1070 & 5.92 & 6.00 & 10.00 & 3.00 & 1.52 \\
OFFICIAL & 1125 & 10.66 & 12.00 & 14.00 & 5.00 & 2.59 \\
INDEPENDENCE & 1142 & 0.83 & 1.00 & 2.00 & 0.00 & 0.58 \\
RLAW & 1142 & 1.44 & 1.55 & 1.93 & -0.39 & 0.42 \\
REGQUAL & 1142 & 1.35 & 1.54 & 1.84 & 0.14 & 0.34 \\
CORR & 1142 & 1.53 & 1.65 & 2.41 & -0.29 & 0.53 \\
\hline & & & & & & \\
\hline
\end{tabular}




\section{Table 9: Baseline Results}

Table 9 presents the regression results for bank performance ( $\overline{R o E_{i}}$ ) and bank risk (DROE). Data on bank performance and bank risk comes from the Bankscope database of Bureau van Dijk. DROE is defined as $1-\left[R o E_{2008}-\overline{R o E}\right]$. A larger value for DROE indicates greater losses in 2008. Regressions use OLS (Model 1) and Two-Stage Least Squares (Model 2 and 3). We test for endogeneity using STATA's endog option. The null hypothesis is that the endogenous variable can be treated as exogenous. The test-statistic is reported at the bottom of Table 9. To control for heteroscedasticity, we use White-robust standard errors (White, 1980). The sample includes 1142 banks. For a complete list and a description of the variables used in the regression analysis see Tables 7 and 8 .

\begin{tabular}{|c|c|c|c|c|c|c|}
\hline & \multicolumn{2}{|c|}{ Model 1} & \multicolumn{2}{|c|}{ Model 2} & \multicolumn{2}{|c|}{$\begin{array}{l}\text { Model } 3 \\
\text { Baseline }\end{array}$} \\
\hline & ROE & DROE & ROE & DROE & ROE & DROE \\
\hline STAKE & $\begin{array}{l}0.000195^{* *} \\
(2.34)\end{array}$ & $\begin{array}{l}-0.000615^{* * *} \\
(-2.76)\end{array}$ & $\begin{array}{l}0.00523 * * * \\
(4.49)\end{array}$ & $\begin{array}{l}0.00595 * * * \\
(3.00)\end{array}$ & $\begin{array}{l}0.00362 * * * \\
(5.63)\end{array}$ & $\begin{array}{l}0.00348 * * * \\
(2.82)\end{array}$ \\
\hline RIGHTS & $\begin{array}{l}0.0136^{* * *} \\
(6.88)\end{array}$ & $\begin{array}{l}0.0216^{* * *} \\
(3.69)\end{array}$ & $\begin{array}{l}0.0568 * * * \\
(5.21)\end{array}$ & $\begin{array}{l}0.0778^{* * *} \\
(4.08)\end{array}$ & $\begin{array}{l}0.0310^{* * * *} \\
(5.89)\end{array}$ & $\begin{array}{l}0.0428^{* * * *} \\
(3.84)\end{array}$ \\
\hline HOLDING & & & & & $\begin{array}{l}0.135^{* * *} \\
(5.70)\end{array}$ & $\begin{array}{l}0.162 * * * \\
(3.55)\end{array}$ \\
\hline SAVINGS & & & & & $\begin{array}{l}0.0381 * * \\
(2.48)\end{array}$ & $\begin{array}{l}0.0719 * * \\
(2.14)\end{array}$ \\
\hline COOPERATIV & & & & & $\begin{array}{l}0.0938^{* * * *} \\
(3.80)\end{array}$ & $\begin{array}{l}0.0592 \\
(1.44)\end{array}$ \\
\hline INVESTMENT & & & & & $\begin{array}{l}0.0116 \\
(0.46)\end{array}$ & $\begin{array}{l}0.00591 \\
(0.11)\end{array}$ \\
\hline MORTGAGE & & & & & $\begin{array}{l}0.00356 \\
(0.17)\end{array}$ & $\begin{array}{l}-0.0309 \\
(-0.75)\end{array}$ \\
\hline STATE-BANK & & & & & $\begin{array}{l}-0.0583 * * * \\
(-3.30)\end{array}$ & $\begin{array}{l}-0.00258 \\
(-0.06)\end{array}$ \\
\hline Observations & 1,142 & 1,142 & 1,142 & 1,142 & 1,142 & 1,142 \\
\hline F-test of & & & $24.20 * * *$ & $24.20 * * *$ & $48.18 * * *$ & $48.18 * * *$ \\
\hline Endogeneity & & & $66.77 * * *$ & $20.97 * * *$ & $58.34 * * *$ & $14.83 * * *$ \\
\hline
\end{tabular}

***/**/* indicates significance at the $1-/ 5-/ 10-\%$ level. 


\section{Table 10: Bank Characteristics}

Table 10 presents the results of robustness checks controlling for bank characteristics. Data on bank performance $\left(\overline{R o E_{i}}\right.$ ) and bank risk (DROE) comes from the Bankscope database of Bureau van Dijk. DROE is defined as $1-\left[R o E_{2008}-\overline{R O E}\right]$. A larger value for DROE, hence, indicates greater losses in 2008. Since tests indicate that STAKE is endogenous, we only report the results of Two-Stage Least Squares regressions. We test for endogeneity using STATA's endog option. The null hypothesis is that the endogenous variable can be treated as exogenous. The test-statistic is reported at the bottom of Table 10. To control for heteroscedasticity, we use White-robust standard errors (White, 1980). The sample includes 1142 banks. Since data on the bank characteristics is not available for the full samples, the number of observations in the regression including the bank variables is smaller than in the baseline model. For a complete list and a description of the variables used in the regression analysis see Tables 7 and 8 .

\begin{tabular}{|c|c|c|c|c|}
\hline & State & $\begin{array}{l}\text { lel } 4 \\
\text { ign Ownership }\end{array}$ & Ban & $\begin{array}{l}\text { del } 5 \\
\text { aracteristics }\end{array}$ \\
\hline & ROE & DROE & ROE & DROE \\
\hline STAKE & $\begin{array}{l}0.0127^{* *} \\
(2.15)\end{array}$ & $\begin{array}{l}0.0154^{*} \\
(1.79)\end{array}$ & $\begin{array}{l}0.00437 * * * \\
(4.99)\end{array}$ & $\begin{array}{l}0.00458^{* * * *} \\
(2.93)\end{array}$ \\
\hline RIGHTS & $\begin{array}{l}0.0721 * * \\
(2.46)\end{array}$ & $\begin{array}{l}0.0971 * * \\
(2.22)\end{array}$ & $\begin{array}{l}0.0294 * * * \\
(5.47)\end{array}$ & $\begin{array}{l}0.0442^{* * *} \\
(4.23)\end{array}$ \\
\hline HOLDING & $\begin{array}{l}0.147 * * * \\
(2.59)\end{array}$ & $\begin{array}{l}0.172^{* *} \\
(2.08)\end{array}$ & $\begin{array}{l}0.166^{* * *} \\
(5.22)\end{array}$ & $\begin{array}{l}0.209 * * * \\
(3.67)\end{array}$ \\
\hline SAVINGS & $\begin{array}{l}0.203^{* * *} \\
(2.01)\end{array}$ & $\begin{array}{l}0.301 * * \\
(2.01)\end{array}$ & $\begin{array}{l}0.0365 * * \\
(2.04)\end{array}$ & $\begin{array}{l}0.0719^{* *} \\
(2.03)\end{array}$ \\
\hline COOPERATIVE & $\begin{array}{l}0.392 * * \\
(1.96)\end{array}$ & $\begin{array}{l}0.460 \\
(1.58)\end{array}$ & $\begin{array}{l}0.110^{* * *} \\
(3.51)\end{array}$ & $\begin{array}{l}0.0708 \\
(1.42)\end{array}$ \\
\hline INVESTMENT & $\begin{array}{l}-0.0468 \\
(-0.66)\end{array}$ & $\begin{array}{l}-0.0767 \\
(-0.75)\end{array}$ & $\begin{array}{l}0.0339 \\
(1.01)\end{array}$ & $\begin{array}{l}0.0459 \\
(0.73)\end{array}$ \\
\hline MORTGAGE & $\begin{array}{l}0.0993 \\
(1.22)\end{array}$ & $\begin{array}{l}0.106 \\
(0.91)\end{array}$ & $\begin{array}{l}-0.0298 \\
(-1.12)\end{array}$ & $\begin{array}{l}-0.0427 \\
(-0.88)\end{array}$ \\
\hline STATE-BANK & $\begin{array}{l}-0.00767 \\
(-0.12)\end{array}$ & $\begin{array}{l}0.125 \\
(1.28)\end{array}$ & $\begin{array}{l}-0.0698^{* * * *} \\
(-3.10)\end{array}$ & $\begin{array}{l}-0.0186 \\
(-0.38)\end{array}$ \\
\hline LIST & $\begin{array}{l}0.583^{* *} \\
(2.00)\end{array}$ & $\begin{array}{l}0.778^{*} \\
(1.82)\end{array}$ & & \\
\hline STATE & $\begin{array}{l}-0.211 * \\
(-1.74)\end{array}$ & $\begin{array}{l}-0.380^{* *} \\
(-2.26)\end{array}$ & & \\
\hline FOREIGN & $\begin{array}{l}-0.0750^{* *} \\
(-2.27)\end{array}$ & $\begin{array}{l}-0.0672 \\
(-1.39)\end{array}$ & & \\
\hline SIZE & & & $\begin{array}{l}0.0102 * * \\
(2.21)\end{array}$ & $\begin{array}{l}0.0234^{* * * *} \\
(2.63)\end{array}$ \\
\hline CAPITAL & & & $\begin{array}{l}-0.000750 \\
(-0.63)\end{array}$ & $\begin{array}{l}-0.00181 \\
(-0.97)\end{array}$ \\
\hline DEPOSITS & & & $\begin{array}{l}0.0629 * \\
(1.89)\end{array}$ & $\begin{array}{l}0.0334 \\
(0.54)\end{array}$ \\
\hline LOANS & & & $\begin{array}{l}0.102^{* * *} \\
(2.97)\end{array}$ & $\begin{array}{l}0.188^{* * * *} \\
(2.96)\end{array}$ \\
\hline Observations & 1,142 & 1,142 & 1,073 & 1,073 \\
\hline F-test of excluded instruments & $5.04 * *$ & $5.04 * *$ & $33.48 * * *$ & $33.48^{* * *}$ \\
\hline Endogeneity test-statistic & $51.22 * * *$ & $13.07^{* * *}$ & $66.28 * * *$ & $17.13^{* * *}$ \\
\hline
\end{tabular}

$* * * / * * / *$ indicates significance at the $1-/ 5-/ 10-\%$ level. 


\section{Table 11: Banking Regulation and Supervision}

Table 11 presents the results of robustness checks controlling for the level of banking regulation and supervision. Data on bank performance $\left(\overline{\operatorname{RoE}_{i}}\right)$ and bank risk (DROE) comes from the Bankscope database of Bureau van Dijk. DROE is defined as $1-\left[R o E_{2008}-\overline{R o E}\right]$. A larger value for DROE, hence, indicates greater losses in 2008. Since tests indicate that STAKE is endogenous, we only report the results of Two-Stage Least Squares regressions. We test for endogeneity using STATA's endog option. The null hypothesis is that the endogenous variable can be treated as exogenous. The test-statistic is reported at the bottom of Table 11 . To control for heteroscedasticity, we use White-robust standard errors (White, 1980). The sample includes 1142 banks. Since data on banking regulation and supervision is not available for all countries, the number of observations in the regressions including the banking regulation and supervision is smaller than in the baseline model. For a complete list and a description of the variables used in the regression analysis see Tables 7 and 8 .

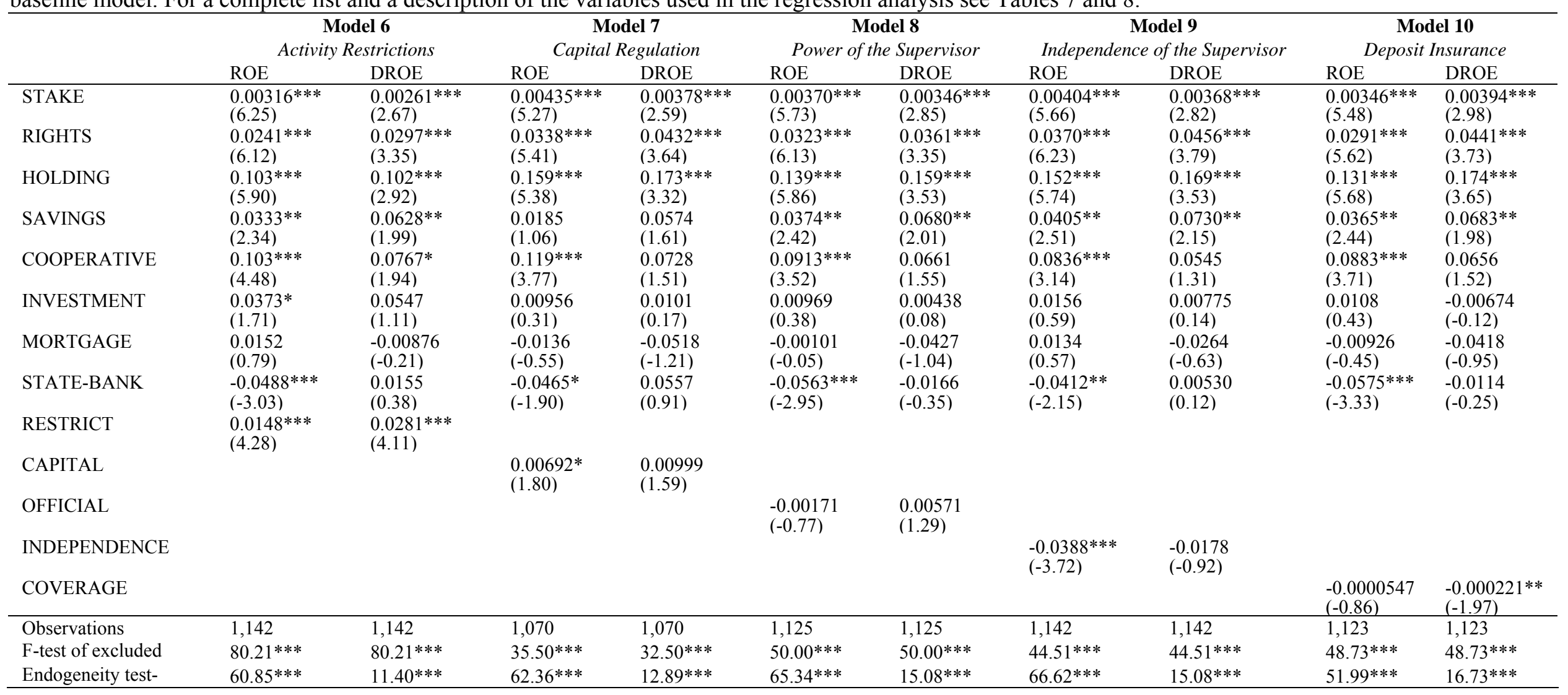

$* * * / * * / *$ indicates significance at the $1-/ 5-/ 10-\%$ level. 


\section{Table 12: Other Country Characteristics}

Table 12 presents the results of robustness checks controlling other country characteristics. Data on bank performance (ROE) and bank risk ( $\left.\overline{R o E_{i}}\right)$ comes from the Bankscope database of Bureau van Dijk. DROE is defined as $1-\left[\operatorname{RoE}_{2008}-\overline{R o E}\right]$. A larger value for DROE, hence, indicates greater losses in 2008 and greater risk-taking. Since tests indicate that STAKE is endogenous, we only report the results of Two-Stage Least Squares (IV) regressions. We test for endogeneity using STATA's endog option. The null hypothesis is that the endogenous variable can be treated as exogenous. The test-statistic is reported at the bottom of Table 12. To control for heteroscedasticity, we use White-robust standard errors (White, 1980). The sample includes 1142 banks. Since data on banking regulation and supervision is not available for all countries, the number of observations in the regressions including other country characteristics is smaller than in the baseline model. For a complete list and a description of the variables used in the regression analysis see Table 7 and 8.

\begin{tabular}{|c|c|c|c|c|c|c|c|c|}
\hline & \multirow{2}{*}{\multicolumn{2}{|c|}{$\begin{array}{l}\text { Model } 11 \\
\text { Rule of Law }\end{array}$}} & \multirow{2}{*}{\multicolumn{2}{|c|}{$\begin{array}{c}\text { Model } 12 \\
\text { Regulatory Quality }\end{array}$}} & \multirow{2}{*}{\multicolumn{2}{|c|}{$\begin{array}{l}\text { Model } 13 \\
\text { Corruption }\end{array}$}} & \multirow{2}{*}{\multicolumn{2}{|c|}{$\begin{array}{c}\text { Model } 14 \\
\text { Banking Market Structure }\end{array}$}} \\
\hline & & & & & & & & \\
\hline & ROE & DROE & ROE & DROE & ROE & DROE & ROE & DROE \\
\hline STAKE & $\begin{array}{l}0.00362 * * * \\
(5.63)\end{array}$ & $\begin{array}{l}0.00349^{* * *} \\
(2.82)\end{array}$ & $\begin{array}{l}0.00424 * * * \\
(4.11)\end{array}$ & $\begin{array}{l}0.00382 * * \\
(2.11)\end{array}$ & $\begin{array}{l}0.00373 * * * \\
(5.41)\end{array}$ & $\begin{array}{l}0.00359^{* * *} \\
(2.74)\end{array}$ & $\begin{array}{l}0.00213^{* * *} \\
(4.02)\end{array}$ & $\begin{array}{l}0.00265 * * \\
(2.04)\end{array}$ \\
\hline RIGHTS & $\begin{array}{l}0.0333 * * * \\
(5.66)\end{array}$ & $\begin{array}{l}0.0438 * * * \\
(3.55)\end{array}$ & $\begin{array}{l}0.0374 * * * \\
(4.16)\end{array}$ & $\begin{array}{l}0.0462 * * * \\
(2.78)\end{array}$ & $\begin{array}{l}0.0341 * * * \\
(5.42)\end{array}$ & $\begin{array}{l}0.0458^{* * *} \\
(3.53)\end{array}$ & $\begin{array}{l}0.0208^{* * * *} \\
(4.88)\end{array}$ & $\begin{array}{l}0.0240 * * \\
(2.30)\end{array}$ \\
\hline HOLDING & $\begin{array}{l}0.135^{* * * *} \\
(5.70)\end{array}$ & $\begin{array}{l}0.162 * * * \\
(3.55)\end{array}$ & $\begin{array}{l}0.159 * * * \\
(4.15)\end{array}$ & $\begin{array}{l}0.174 * * * \\
(2.64)\end{array}$ & $\begin{array}{l}0.139 * * * \\
(5.49)\end{array}$ & $\begin{array}{l}0.166^{* * *} \\
(3.47)\end{array}$ & $\begin{array}{l}0.0710^{* * *} \\
(3.51)\end{array}$ & $\begin{array}{l}0.120^{* *} \\
(2.33)\end{array}$ \\
\hline SAVINGS & $\begin{array}{l}0.0403^{* * *} \\
(2.63)\end{array}$ & $\begin{array}{l}0.0729 * * \\
(2.14)\end{array}$ & $\begin{array}{l}0.0451^{* *} \\
(2.48)\end{array}$ & $\begin{array}{l}0.0756^{* *} \\
(2.07)\end{array}$ & $\begin{array}{l}0.0413 * * * \\
(2.62)\end{array}$ & $\begin{array}{l}0.0750^{* *} \\
(2.18)\end{array}$ & $\begin{array}{l}0.0126 \\
(1.05)\end{array}$ & $\begin{array}{l}0.0687^{* *} \\
(1.97)\end{array}$ \\
\hline COOPERATIVE & $\begin{array}{l}0.0928 * * * \\
(3.85)\end{array}$ & $\begin{array}{l}0.0588 \\
(1.45)\end{array}$ & $\begin{array}{l}0.107 * * * \\
(3.22)\end{array}$ & $\begin{array}{l}0.0665 \\
(1.27)\end{array}$ & $\begin{array}{l}0.0952 * * * \\
(3.78)\end{array}$ & $\begin{array}{l}0.0606 \\
(1.45)\end{array}$ & $\begin{array}{l}0.0419^{* *} \\
(2.13)\end{array}$ & $\begin{array}{l}0.0347 \\
(0.78)\end{array}$ \\
\hline INVESTMENT & $\begin{array}{l}0.0150 \\
(0.61)\end{array}$ & $\begin{array}{l}0.00748 \\
(0.14)\end{array}$ & $\begin{array}{l}0.0118 \\
(0.44)\end{array}$ & $\begin{array}{l}0.00605 \\
(0.11)\end{array}$ & $\begin{array}{l}0.0158 \\
(0.63)\end{array}$ & $\begin{array}{l}0.00995 \\
(0.19)\end{array}$ & $\begin{array}{l}0.0315 \\
(1.60)\end{array}$ & $\begin{array}{l}0.0308 \\
(0.59)\end{array}$ \\
\hline MORTGAGE & $\begin{array}{l}0.0117 \\
(0.53)\end{array}$ & $\begin{array}{l}-0.0272 \\
(-0.63)\end{array}$ & $\begin{array}{l}0.0159 \\
(0.60)\end{array}$ & $\begin{array}{l}-0.0243 \\
(-0.52)\end{array}$ & $\begin{array}{l}0.0147 \\
(0.64)\end{array}$ & $\begin{array}{l}-0.0201 \\
(-0.45)\end{array}$ & $\begin{array}{l}-0.00673 \\
(-0.42)\end{array}$ & $\begin{array}{l}-0.0225 \\
(-0.54)\end{array}$ \\
\hline STATE-BANK & $\begin{array}{l}-0.0523 * * * \\
(-2.91)\end{array}$ & $\begin{array}{l}0.000162 \\
(0.00)\end{array}$ & $\begin{array}{l}-0.0566^{* * *} \\
(-2.89)\end{array}$ & $\begin{array}{l}-0.00166 \\
(-0.04)\end{array}$ & $\begin{array}{l}-0.0519 * * * \\
(-2.84)\end{array}$ & $\begin{array}{l}0.00369 \\
(0.08)\end{array}$ & $\begin{array}{l}-0.0455 * * * \\
(-3.11)\end{array}$ & $\begin{array}{l}0.0207 \\
(0.48)\end{array}$ \\
\hline RULE OF LAW & $\begin{array}{l}-0.0220 \\
(-1.64)\end{array}$ & $\begin{array}{l}-0.0100 \\
(-0.39)\end{array}$ & & & & & & \\
\hline REGULATORY QUALITY & & & $\begin{array}{l}-0.0369 \\
(-1.26)\end{array}$ & $\begin{array}{l}-0.0198 \\
(-0.38)\end{array}$ & & & & \\
\hline CORRUPTION & & & & & $\begin{array}{l}-0.0215^{*} \\
(-1.74)\end{array}$ & $\begin{array}{l}-0.0208 \\
(-0.88)\end{array}$ & & \\
\hline DBAGDP & & & & & & & $\begin{array}{l}-0.0703 * * * \\
(-5.02)\end{array}$ & $\begin{array}{l}0.00727 \\
(0.21)\end{array}$ \\
\hline $\mathrm{C} 3$ & & & & & & & $\begin{array}{l}0.0538^{*} \\
(1.78)\end{array}$ & $\begin{array}{l}-0.192 * * \\
(-2.50)\end{array}$ \\
\hline Observations & 1,142 & 1,142 & 1,142 & 1,142 & 1,142 & 1,142 & 1,142 & 1,142 \\
\hline F-test of excluded instruments & $48.85 * * *$ & $48.85 * * *$ & $23.53 * * *$ & $23.53 * * *$ & $44.68 * * *$ & $44.68 * * *$ & $40.45 * * *$ & $40.45 * * *$ \\
\hline Endogeneity test-statistic & $58.89 * * *$ & $15.10 * * *$ & $47.38 * * *$ & $8.843 * * *$ & $59.10 * * *$ & $14.34 * * *$ & $25.55 * * *$ & $8.08 * * *$ \\
\hline
\end{tabular}

$* * * / * * / *$ indicates significance at the $1-/ 5-/ 10-\%$ level. 


\section{Table 13: Further Robustness Checks and Model Extensions}

Table 13 presents the results of further robustness checks and model extensions. Columns 1 and 2 report the results of the baseline model including SMOOTHING. SMOOTHING is defined as one minus the ratio of the bank-level standard deviation of operating income divided by the bank-level standard deviation of cash flow operations between 2000 and 2006. Data on bank performance (ROE) and bank risk (DROE) comes from the Bankscope database of Bureau van Dijk. DROE is defined as $1-\left[\operatorname{RoE}_{2008}-\overline{R o E}\right]$. A larger value for DROE, hence, indicates greater losses in 2008. Since tests indicate that STAKE is endogenous, we only report the results of Two-Stage Least Squares (IV) regressions. We test for endogeneity using STATA's endog option. The null hypothesis is that the endogenous variable can be treated as exogenous. The teststatistic is reported at the bottom of Table 13. To control for heteroscedasticity, we use White-robust standard errors (White, 1980). The third column reports the results of an instrumental variables probit regression. The dependent variable is a dummy variable that is one if a bank received any kind of financial support from the government during the crisis and zero otherwise (GOVAID). For a complete list and a description of the variables used in the regression analysis see Table 7 and 8.

\begin{tabular}{lccc}
\hline & \multicolumn{2}{c}{ Model 15 } & Model 16 \\
& \multicolumn{2}{c}{ Profit Smoothing } & Instrumental Variables Probit \\
& ROE & DROE & GOVAID \\
\hline STAKE & $0.00366^{* * *}$ & $0.00321^{* *}$ & $0.02522^{* * *}$ \\
& $(5.37)$ & $(2.54)$ & -0.008 \\
RIGHTS & $0.0320^{* * *}$ & $0.0407^{* * *}$ & $0.268^{* * *}$ \\
& $(5.81)$ & $(3.60)$ & $(0.0611)$ \\
HOLDING & $0.133^{* * *}$ & $0.152^{* * *}$ & $2.055^{* * *}$ \\
& $(5.47)$ & $(3.33)$ & $(0.321)$ \\
SAVINGS & $0.0356^{* *}$ & $0.0729^{* *}$ & 0.118 \\
& $(2.29)$ & $(2.15)$ & $(0.255)$ \\
COOPERATIVE & $0.0979^{* * *}$ & 0.0508 & $0.785^{* *}$ \\
& $(3.81)$ & $(1.23)$ & $(0.348)$ \\
INVESTMENT & -0.000430 & 0.0280 & $-0.659^{*}$ \\
& $(-0.02)$ & $(0.50)$ & $(0.339)$ \\
MORTGAGE & -0.000603 & -0.0316 & 0.267 \\
& $(-0.03)$ & $(-0.73)$ & $(0.278)$ \\
STATE-BANK & $-0.0615^{* * *}$ & -0.0226 & 0.109 \\
& $(-3.33)$ & $(-0.49)$ & $(0.269)$ \\
SMOOTHING & $-0.0629^{* *}$ & -0.00706 & \\
& $(-2.03)$ & $(-0.13)$ & 1142 \\
\hline Observations & 1100 & 1100 & \\
F-test of excluded instruments & $43.72^{* * *}$ & $43.72^{* * *}$ & \\
Endogeneity test-statistic & $55.85^{* * *}$ & $12.59^{* * *}$ & \\
\hline
\end{tabular}

$* * * / * * / *$ indicates significance at the $1-/ 5-/ 10-\%$ level. 


\section{Figure 1: Relationship between Bank Risk and Bank Performance}

Figure 1 illustrates the relationship between bank performance and bank risk-taking. Bank performance is measured by the average return-on-equity (ROE) in the period between 2000 and 2006. Bank risk is measured by the drop-off in ROE in 2008 from the average ROE in the period between 2000 and 2006 (DROE). To eliminate outliers, all variables are winsorized at the 1- and 99-percent level. DROE is constructed in a way that a higher value for DROE indicates greater risk-taking. To make interpretation easier, we calculate the average ROE for every decile of the distribution. Hence, each dot reflects the combination of average bank performance in each decile and the corresponding average value for bank risktaking in the respective decile. $* * * / * * * *$ indicates significance at the 1-/5-/10-percent level.

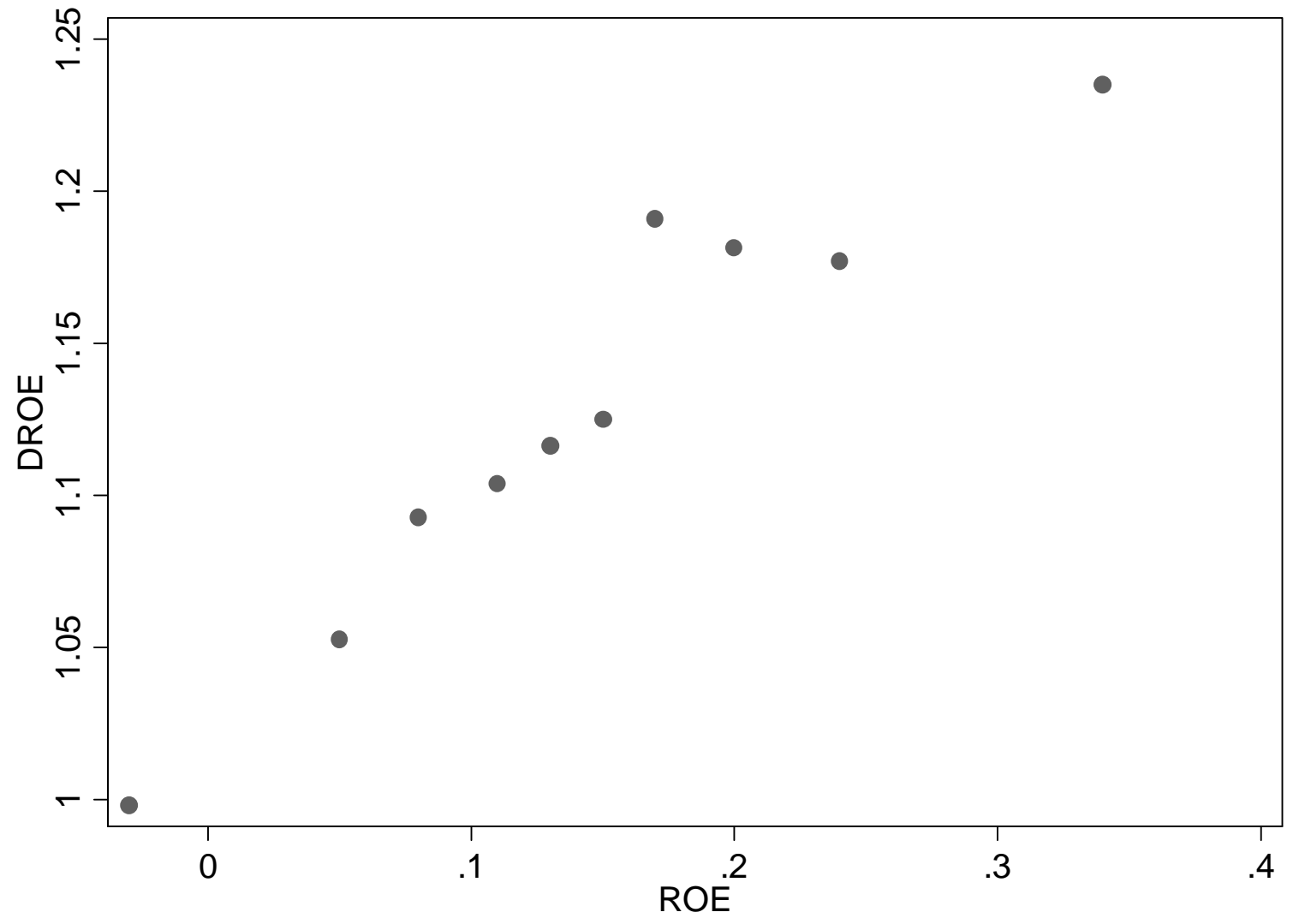

Correlation between DROE and ROE for the full sample: $0.2474 * * *$ 